Supporting Information for

\title{
Alkoxy Chain Number Effect on Self-Assembly of a Trigonal Molecule at the Liquid/Solid Interface
}

\author{
Kazukuni Tahara ${ }^{*, \dagger}$ Ruri Nakayama,$^{\dagger}$ Matsuhiro Maeda ${ }^{\dagger}$ Steven De Feyter,,$*$ \\ Yoshito Tobe $*, \#, \S$
}

†Department of Applied Chemistry, School of Science and Technology, Meiji University, 1-1-1 Higashimita, Tama-ku, Kawasaki, Kanagawa, 214-8571, Japan

Division of Molecular Imaging and Photonics, Department of Chemistry, KU Leuven, Celestijnenlaan 200 F, 3001 Leuven, Belgium

\#The Institute of Scientific and Industrial Research, Osaka University, Ibaraki, Osaka 567-0047, Japan

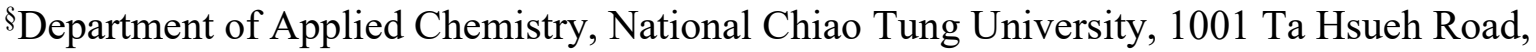
Hsinchu 30030, Taiwan

correspondence to: tahara@meiji.ac.jp, steven.defeyter@kuleuven.be, tobe@chem.es.osaka-u.ac.jp.

\section{This file includes:}

1. Synthesis of DBA-OC14-OC1

2. STM Images of Monolayers Formed by DBA-OC14-OMOM

3. Additional STM Images of Monolayers Formed by DBA-OC14-OC1

4. Details on MM Simulations

5. Energy Estimation for Monolayer Networks by MM Simulations

6. Estimation of Entropy Changes upon Desorption of DBA and Solvent Molecules

7. ${ }^{1} \mathrm{H}$ and ${ }^{13} \mathrm{C}$ Spectra of DBA-OC14-OC1

8. Cartesian Coordinates of Optimized Geometries $\quad$ S21

9. References 


\section{Synthesis of DBA-OC14-OC1.}

The synthesis of DBA-OC14-OC1 was conducted according to a previously reported method (Scheme S1). ${ }^{1}$

Scheme S1. Synthesis of DBA-O14-OC1.

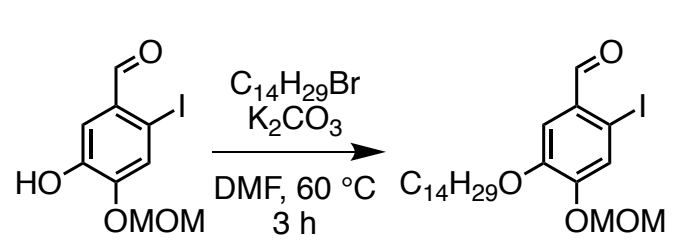

$\mathrm{MOM}=\boldsymbol{\xi}^{-} \mathrm{O}^{\prime}$

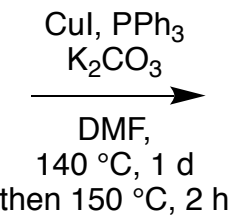

$1,72 \%$

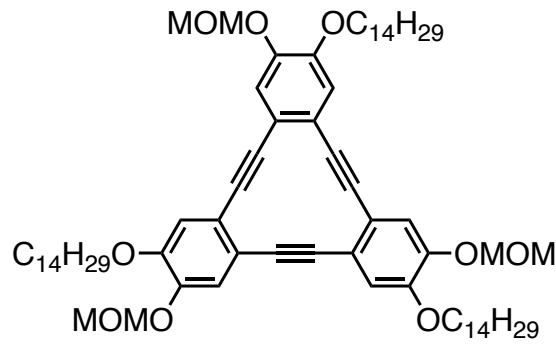

DBA-OC14-OMOM, $20 \%$

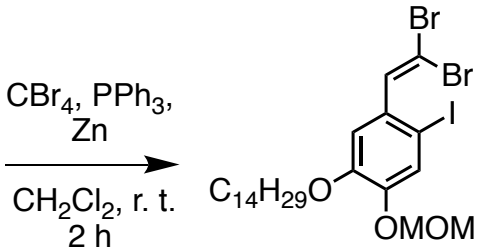

2, $89 \%$

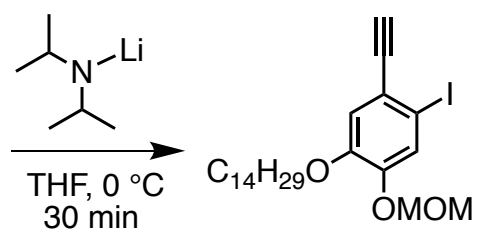

3, $74 \%$
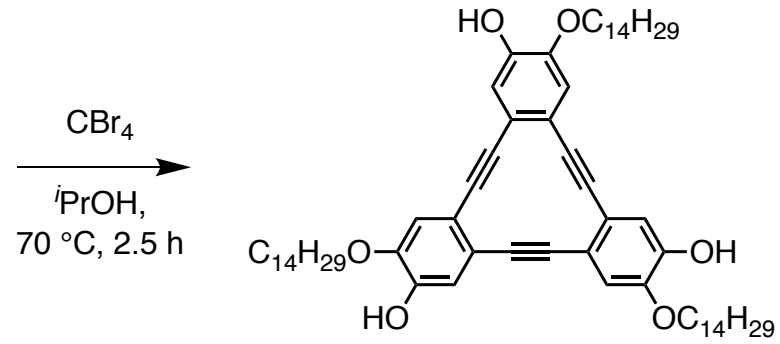

DBA-OC14-OH, 99\%

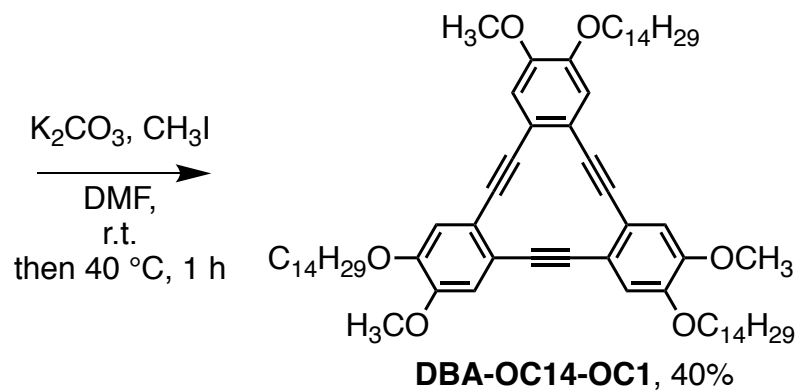

General. All solvents were distilled or passed through activated alumina and copper catalyst in a Glass Contour solvent purification system prior use. All commercially available reagents were used as received.

${ }^{1} \mathrm{H}(500,400$ or $270 \mathrm{MHz})$ and ${ }^{13} \mathrm{C}(125,100$ or $67.5 \mathrm{MHz}) \mathrm{NMR}$ spectra were measured on a JEOL ECA-500, ECA-400 or JNM-GSX270 spectrometer. For NMR measurements, chloroform- $d$ was used as solvent, and the spectra were referenced to tetramethylsilane in the ${ }^{1} \mathrm{H}$ and ${ }^{13} \mathrm{C}$ NMR spectra $(0 \mathrm{ppm})$. Other spectra were recorded by the use of the following instruments: IR spectra, JACSCO FT/IR-410; mass spectra, JMS-T100GCV.

Synthesis of 2-Iodo-4-(methoxymethoxy)-5-tetradecyloxybenzaldehyde (1). Under argon atmosphere, 5-hydroxy-2-iodo-4-(methoxymethoxy)benzaldehyde ( $806 \mathrm{mg}, 2.62 \mathrm{mmol})^{2}$ and $\mathrm{K}_{2} \mathrm{CO}_{3}$ (725 mg, $5.25 \mathrm{mmol})$ were added to a Schlenk tube. Then, DMF (12 mL) was added. To this suspension, 1-bromotetradecane $(1.05 \mathrm{~mL}, 1.07 \mathrm{~g}, 3.86 \mathrm{mmol})$ was added via a syringe. After stirring 
at $60{ }^{\circ} \mathrm{C}$ for $3 \mathrm{~h}$, the reaction was quenched by the addition of sat. $\mathrm{NH}_{4} \mathrm{Cl}$ aq. $(20 \mathrm{~mL})$. The mixture was diluted by $\mathrm{CH}_{2} \mathrm{Cl}_{2}$, and added to a separatory funnel. The product was extracted with $\mathrm{CH}_{2} \mathrm{Cl}_{2}$. The organic phase was washed with water and brine, and dried over $\mathrm{MgSO}_{4}$. After evaporation of the solvent, the residue was subjected to recrystallization $\left(\mathrm{CH}_{2} \mathrm{Cl}_{2} /\right.$ hexane) to furnish 1 (948 $\left.\mathrm{mg}, 72 \%\right)$ as white crystals. $\mathrm{mp} 84.2-84.8{ }^{\circ} \mathrm{C} ;{ }^{1} \mathrm{H} \mathrm{NMR}\left(500 \mathrm{MHz}, \mathrm{CDCl}_{3}, 25.0{ }^{\circ} \mathrm{C}\right) \delta 9.88(\mathrm{~s}, 1 \mathrm{H}), 7.61(\mathrm{~s}, 1 \mathrm{H})$, $7.43(\mathrm{~s}, 1 \mathrm{H}), 5.28(\mathrm{~s}, 2 \mathrm{H}), 4.05(\mathrm{t}, 2 \mathrm{H}, J=6.5 \mathrm{~Hz}), 3.52$ (s, 3H), 1.83 (quint, 2H, $J=7.2 \mathrm{~Hz}$ ), 1.47$1.22(\mathrm{~m}, 22 \mathrm{H}), 0.88(\mathrm{t}, 3 \mathrm{H}, J=6.8 \mathrm{~Hz}) ;{ }^{13} \mathrm{C} \mathrm{NMR}\left(125 \mathrm{MHz}, \mathrm{CDCl}_{3}, 19.6{ }^{\circ} \mathrm{C}\right) \delta 195.1,152.3,149.9$, $129.3,126.3$, 112.8, 95.1, 91.8, 69.1, 56.6, 31.9, 29.68, 29.66, 29.58, 29.55, 29.4, 29.3, 28.8, 25.9, 22.7, 14.1; IR (KBr): 3345, 3100, 3078, 2920, 2848, 2754, 1685, 1581, 1499, 1468, 1381, 1327, 1262 , 1163, 1081, $974 \mathrm{~cm}^{-1}$; MS (FD): $m / z$ calcd for $\mathrm{C}_{23} \mathrm{H}_{37} \mathrm{O}_{4} \mathrm{I}\left(\mathrm{M}^{+}\right)$: 504.1737, found: 504.1721 .

Synthesis of 1-(2,2-Dibromoethenyl)-2-iodo-4-(methoxymethoxy)-5-tetradecyloxybenzene (2). Under argon atmosphere, $\mathrm{CBr}_{4}(3.12 \mathrm{~g}, 9.40 \mathrm{mmol}), \mathrm{Zn}(1.56 \mathrm{~g}, 23.8 \mathrm{mmol})$ and $\mathrm{CH}_{2} \mathrm{Cl}_{2}(40 \mathrm{~mL})$ were added to a three-necked flask equipped with a dropping funnel. A solution of $\mathrm{PPh}_{3}(7.89 \mathrm{~g}, 30.1$ mmol) in $\mathrm{CH}_{2} \mathrm{Cl}_{2}(23 \mathrm{~mL})$ was added dropwise via the dropping funnel. After stirring for $1 \mathrm{~h}$, a solution of 1 (3.00 g, $5.95 \mathrm{mmol})$ in $\mathrm{CH}_{2} \mathrm{Cl}_{2}(35 \mathrm{~mL})$ was added to the mixture from the dropping funnel. Further stirring for $2 \mathrm{~h}$, the reaction was terminated by the addition of sat. $\mathrm{NaHCO}_{3}$ aq. The products were extracted with $\mathrm{CHCl}_{3}$. The organic phase was washed with water and brine, and dried over $\mathrm{MgSO}_{4}$. After removal of the solvents, the residue was subjected to the silica gel column chromatography (hexane/ $\left.\mathrm{CH}_{2} \mathrm{Cl}_{2}, 3 / 1\right)$ to give $2\left(3.50 \mathrm{~g}, 89 \%\right.$ ) as a white solid. mp $68.5-69.3{ }^{\circ} \mathrm{C} ;{ }^{1} \mathrm{H}$ NMR $\left(500 \mathrm{MHz}, \mathrm{CDCl}_{3}, 15.4^{\circ} \mathrm{C}\right) \delta 7.54(\mathrm{~s}, 1 \mathrm{H}), 7.36(\mathrm{~s}, 1 \mathrm{H}), 7.11(\mathrm{~s}, 1 \mathrm{H}), 5.20(\mathrm{~s}, 2 \mathrm{H}), 4.01(\mathrm{t}, 2 \mathrm{H}$, $J=6.8 \mathrm{~Hz}$ ), $3.52(\mathrm{~s}, 3 \mathrm{H}), 1.82$ (quint, $2 \mathrm{H}, J=7.4 \mathrm{~Hz}), 1.47-1.21(\mathrm{~m}, 22 \mathrm{H}), 0.88$ (t, 3H, $J=6.8 \mathrm{~Hz})$; ${ }^{13} \mathrm{C}$ NMR $\left(125 \mathrm{MHz}, \mathrm{CDCl}_{3}, 19.8{ }^{\circ} \mathrm{C}\right) \delta 149.3,147.3,140.6,133.6,126.6,114.6,95.5,92.1,86.9$, 69.2, 56.4, 31.9, 29.68, 29.66, 29.59, 29.57, 29.4, 28.9, 25.9, 22.7, 14.1; IR (KBr) 3080, 2952, 2922, 2850, 2827, 1562, 1493, 1468, 1379, 1257, 1149, 1081, 991, 872, $830 \mathrm{~cm}^{-1}$; MS (FD): $\mathrm{m} / z$ calcd for $\mathrm{C}_{24} \mathrm{H}_{37} \mathrm{O}_{3} \mathrm{Br}_{2} \mathrm{I}\left(\mathrm{M}^{+}\right)$: 658.0154, found: 658.0129.

Synthesis of 1-Ethynyl-2-iode-4-(methoxymethoxy)-5-tetradecyloxybenzene (3). Under argon atmosphere, to a mixture of THF $(42.5 \mathrm{~mL})$ and ${ }^{i} \operatorname{Pr}_{2} \mathrm{NH}(1.9 \mathrm{~mL}, 13 \mathrm{mmol})$ in a Schlenk tube, ${ }^{n} \mathrm{BuLi}$ (1.6 $\mathrm{M}$ in hexane, $8.5 \mathrm{~mL}, 14 \mathrm{mmol}$ ) was slowly added via a syringe at $-71{ }^{\circ} \mathrm{C}$. Additional ${ }^{i} \operatorname{Pr}_{2} \mathrm{NH}$ $(0.1 \mathrm{~mL}, 1 \mathrm{mmol})$ was added to the mixture. After $20 \mathrm{~min}$ from the addition of a solution of ${ }^{n} \mathrm{BuLi}$, the mixture was warmed to $0^{\circ} \mathrm{C}$. This lithium diisopropyl amide (LDA) solution was added dropwise to a solution of $2(789 \mathrm{mg}, 1.20 \mathrm{mmol})$ in THF $(11 \mathrm{~mL})$ at $0{ }^{\circ} \mathrm{C}$ placed in another Schlenk tube. After stirring at $0{ }^{\circ} \mathrm{C}$ for $30 \mathrm{~min}$, the reaction mixture was quenched with sat. $\mathrm{NH}_{4} \mathrm{Cl}$ aq. $(20 \mathrm{~mL})$. The products were dissolved in $\mathrm{CHCl}_{3}$. The organic phase was washed with water and brine, and dried over $\mathrm{MgSO}_{4}$. After evaporation of the solvent, purification by a silica gel column chromatography 
(hexane $\left./ \mathrm{CH}_{2} \mathrm{Cl}_{2}, 1 / 1\right)$ gave 3 (439 mg, 74\%) as white crystals. mp 105.7-106.0 ${ }^{\circ} \mathrm{C}$; ${ }^{1} \mathrm{H}$ NMR $(270$ $\left.\mathrm{MHz}, \mathrm{CDCl}_{3}, 21^{\circ} \mathrm{C}\right) \delta 7.50(\mathrm{~s}, 1 \mathrm{H}), 7.01(\mathrm{~s}, 1 \mathrm{H}), 5.19(\mathrm{~s}, 2 \mathrm{H}), 3.97(\mathrm{t}, 2 \mathrm{H}, J=6.8 \mathrm{~Hz}), 3.50(\mathrm{~s}, 3 \mathrm{H})$, $3.31(\mathrm{~s}, 1 \mathrm{H}), 1.81$ (quint, $2 \mathrm{H}, J=6.8 \mathrm{~Hz}), 1.48-1.20(\mathrm{~m}, 22 \mathrm{H}), 0.88(\mathrm{t}, 3 \mathrm{H}, J=6.6 \mathrm{~Hz})$; ${ }^{13} \mathrm{C} \mathrm{NMR}$ $\left(125 \mathrm{MHz}, \mathrm{CDCl}_{3}, 24.7^{\circ} \mathrm{C}\right) \delta 149.4,147.9,126.6,122.5,117.6,95.6,89.2,85.3,79.5,69.2,56.4$, 31.9, 29.68, 29.66, 29.59, 29.56, 29.4, 29.3, 29.0, 25.9, 22.7, 14.1; IR (KBr) 3251, 3086, 2972, 2924, 2872, 2848, 1584, 1498, 1322, 1248, 1158, 1090, 981, $865 \mathrm{~cm}^{-1}$; MS (FD): $\mathrm{m} / z$ calcd for $\mathrm{C}_{24} \mathrm{H}_{37} \mathrm{O}_{3} \mathrm{I}$ $\left(\mathrm{M}^{+}\right):$500.1787, found: 500.1769 .

Synthesis of DBA-OC14-OMOM. Under argon atmosphere, $\mathrm{CuI}$ (25.2 mg, $0.132 \mathrm{mmol}), \mathrm{PPh}_{3}(36.8$ $\mathrm{mg}, 0.140 \mathrm{mmol}), 3$ (204 mg, $0.407 \mathrm{mmol})$ and $\mathrm{K}_{2} \mathrm{CO}_{3}(167 \mathrm{mg}, 1.21 \mathrm{mmol}$ ) were added to a Schlenk tube. DMF (3.5 mL) was added to the mixture. After stirring at $140{ }^{\circ} \mathrm{C}$ for $1 \mathrm{~d}$ and then $150{ }^{\circ} \mathrm{C}$ for 2 $\mathrm{h}$, the reaction was quenched by the addition of sat. $\mathrm{NH}_{4} \mathrm{Cl}$ aq. The mixture was diluted by $\mathrm{CHCl}_{3}$. The organic phase was washed with water and brine, and dried over $\mathrm{MgSO}_{4}$. The solvents were removed under vacuum. The residue was subjected to the silica gel column chromatography (hexane $/ \mathrm{CH}_{2} \mathrm{Cl}_{2}$, from 2/1 to 1/1) to give DBA-OC14-OMOM (30.3 mg, 20\%) as a yellow solid. All spectroscopic data agreed with those in a previous report. ${ }^{3}$

Synthesis of DBA-OC14-OH. Under argon atmosphere, DBA-OC14-OMOM (80.1 mg, $71.6 \mu \mathrm{mol})$ was added to a Schlenk tube. To this Schlenk tube, $\mathrm{CBr}_{4}(9.5 \mathrm{mg}, 29 \mu \mathrm{mol})$ and ${ }^{i} \mathrm{PrOH}(1.2 \mathrm{~mL})$ were added. After stirring at $70{ }^{\circ} \mathrm{C}$ for $2.5 \mathrm{~h}$, the solvent was removed under vacuum. Purification by a silica gel column chromatography (hexane $/ \mathrm{CH}_{2} \mathrm{Cl}_{2}$, from 6/1 to 2/1) gave DBA-OC14-OH (70.1 mg, 99\%) as a yellow solid. All spectroscopic data agreed with those in a previous report. ${ }^{3}$

Synthesis of DBA-OC14-OC1. Under argon atmosphere, $\mathrm{K}_{2} \mathrm{CO}_{3}(47.5 \mathrm{mg}, 344 \mu \mathrm{mol})$, DBA-OC14OH $(31.5 \mathrm{mg}, 31.9 \mu \mathrm{mol})$ and DMF $(1.0 \mathrm{~mL})$ were added to a Schlenk tube. To the resulting mixture, $\mathrm{CH}_{3} \mathrm{I}(14.2 \mu \mathrm{L}, 225 \mu \mathrm{mol})$ was added dropwise via a syringe. After stirring at $40{ }^{\circ} \mathrm{C}$ for $1 \mathrm{~h}$, the reaction was quenched by the addition of sat. $\mathrm{NH}_{4} \mathrm{Cl}$ aq. The product was extracted with $\mathrm{CH}_{2} \mathrm{Cl}_{2}$. The organic phase was washed with water and brine, and dried over $\mathrm{MgSO}_{4}$. After evaporation of the solvents, the residue was passed through a pad of silica gel (hexane/ $\mathrm{CH}_{2} \mathrm{Cl}_{2}, 1 / 1$ ). Recrystallization from hexane afforded DBA-OC14-OC1 (13.1 mg, 40\%) as a yellow solid. mp 77.0-77.8 ${ }^{\circ} \mathrm{C}$; ${ }^{1} \mathrm{H}$ NMR $\left(400 \mathrm{MHz}, \mathrm{CDCl}_{3}, 19.1^{\circ} \mathrm{C}\right) \delta 6.730(\mathrm{~s}, 3 \mathrm{H}), 6.727(\mathrm{~s}, 3 \mathrm{H}), 3.98(\mathrm{t}, 6 \mathrm{H}, J=6.8 \mathrm{~Hz}), 3.85(\mathrm{~s}$, 9H), 1.84 (quint, $6 \mathrm{H}, J=7.2 \mathrm{~Hz}), 1.48-1.21(\mathrm{~m}, 66 \mathrm{H}), 0.88(\mathrm{t}, 9 \mathrm{H}, J=6.6 \mathrm{~Hz}) ;{ }^{13} \mathrm{C} \mathrm{NMR}(125 \mathrm{MHz}$, $\left.\mathrm{CDCl}_{3}, 25.0^{\circ} \mathrm{C}\right) \delta 149.4,148.7,119.8,119.6,115.1,114.1,91.9,69.0,55.9,31.9,29.68,29.66,29.60$, 29.55, 29.4, 29.0, 25.9, 22.7, 14.1; IR (KBr); 2999, 2922, 2851, 1594, 1509, 1468, 1352, 1232, 1074 , 1036, $855 \mathrm{~cm}^{-1}$; MS (FD): $\mathrm{m} / z$ calcd for $\mathrm{C}_{69} \mathrm{H}_{102} \mathrm{O}_{6}\left(\mathrm{M}^{+}\right): 1026.7676$, found: 1026.7709 . 


\section{STM Images of Monolayers Formed by DBA-OC14-OMOM.}

We also performed STM observation of self-assembled monolayers formed by a synthetic intermediate DBA-OC14-OMOM at the TCB/graphite interface (Figure S1). The solute concentration was set to $3 \times 10^{-6} \mathrm{M}$. At this low concentration, this molecule forms a honeycomb structure, similar to DBA-OC14-OC1. Moreover, there are twelve bright features along the rims of the hexagonal pores. These are attributed to co-adsorbed solvent molecules.


Figure S1. STM images (a, b) of monolayers formed by a synthetic intermediate, DBA-OC14OMOM at the TCB/graphite interface $\left(3 \times 10^{-6} \mathrm{M}, I_{\text {set }}=100 \mathrm{pA}, V_{\text {bias }}=-0.39 \mathrm{~V}\right)$. Twelve bright dots along the rims of the hexagonal pore could be co-adsorbed TCB molecules. 

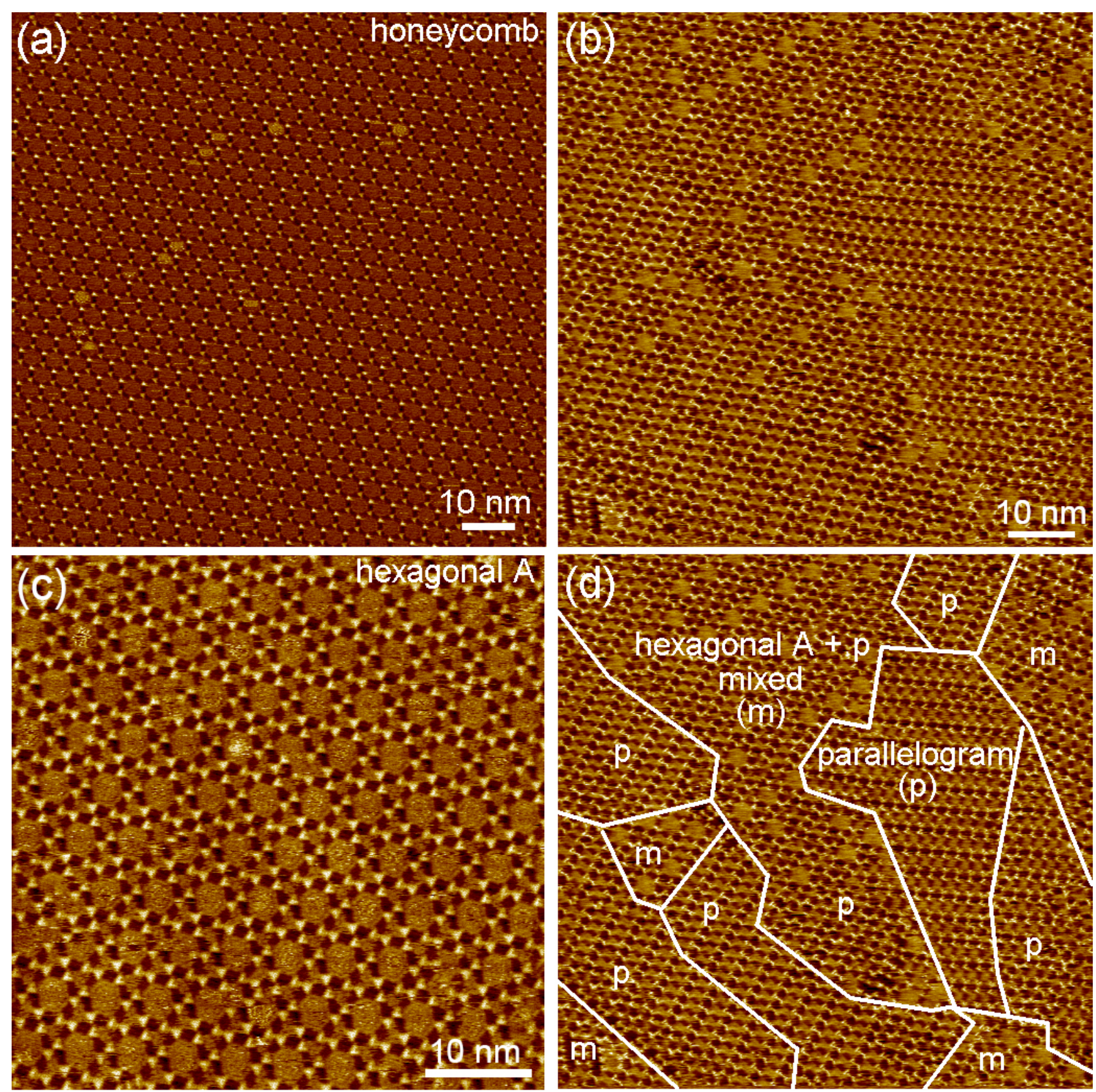

Figure S2. Large area STM images of the monolayers formed by DBA-OC14-OC1 at the

TCB/HOPG interface. (a) The honeycomb structure formed at concentration of $3 \times 10^{-6} \mathrm{M}\left(I_{\text {set }}=250\right.$ $\left.\mathrm{pA}, V_{\text {bias }}=-0.31 \mathrm{~V}\right)$. (b, d) A monolayer consisting of the parallelogram and hexagonal A structures formed at concentration of $6 \times 10^{-5} \mathrm{M}\left(I_{\text {set }}=125 \mathrm{pA}, V_{\text {bias }}=-0.27 \mathrm{~V}\right)$. In image $(\mathrm{d})$, white lines are domain boundaries, and " $p$ " and " $m$ " indicate parallelogram domains and structures consisted of the parallelogram and hexagonal A structures. (c) The hexagonal A structures formed at concentration of $7 \times 10^{-4} \mathrm{M}\left(I_{\text {set }}=250 \mathrm{pA}, V_{\text {bias }}=-0.49 \mathrm{~V}\right)$. 

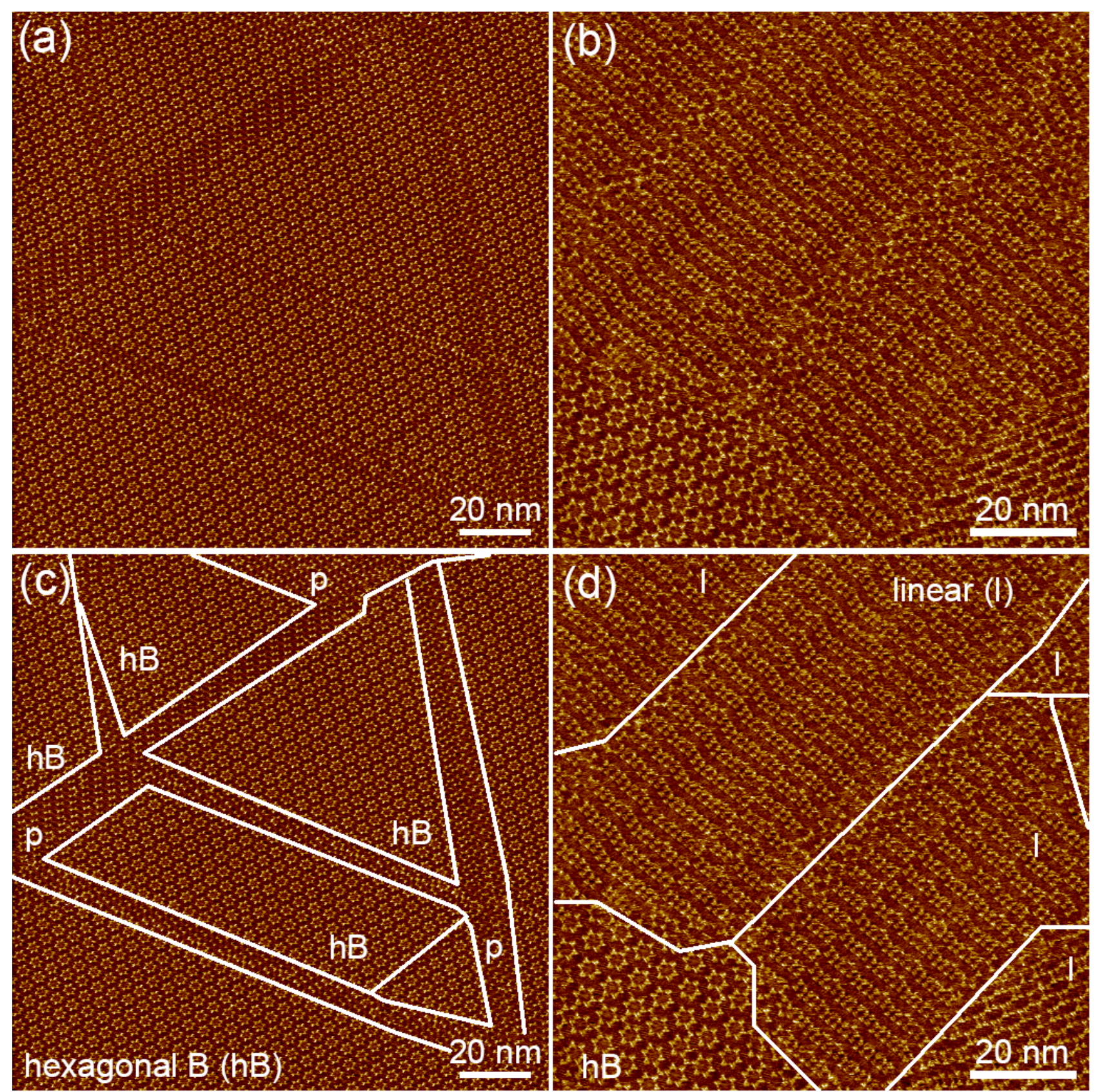

Figure S3. Large area STM images of the monolayers formed by DBA-OC14-OC1 at the PO/HOPG interface. (a, c) A monolayer formed at concentration of $1 \times 10^{-6} \mathrm{M}\left(I_{\text {set }}=350 \mathrm{pA}, V_{\text {bias }}=-0.31 \mathrm{~V}\right)$. The parallelogram and hexagonal B structures coexist. (b, d) A monolayer formed at concentration of $5 \times 10^{-5} \mathrm{M}\left(I_{\text {set }}=100 \mathrm{pA}, V_{\text {bias }}=-0.35 \mathrm{~V}\right)$. The hexagonal B and dense-linear structures coexist. In images (b, d), white lines are domain boundaries, and "p", "hB" and "l" indicate parallelogram, hexagonal porous $\mathrm{B}$, and dense-linear domains, respectively. 


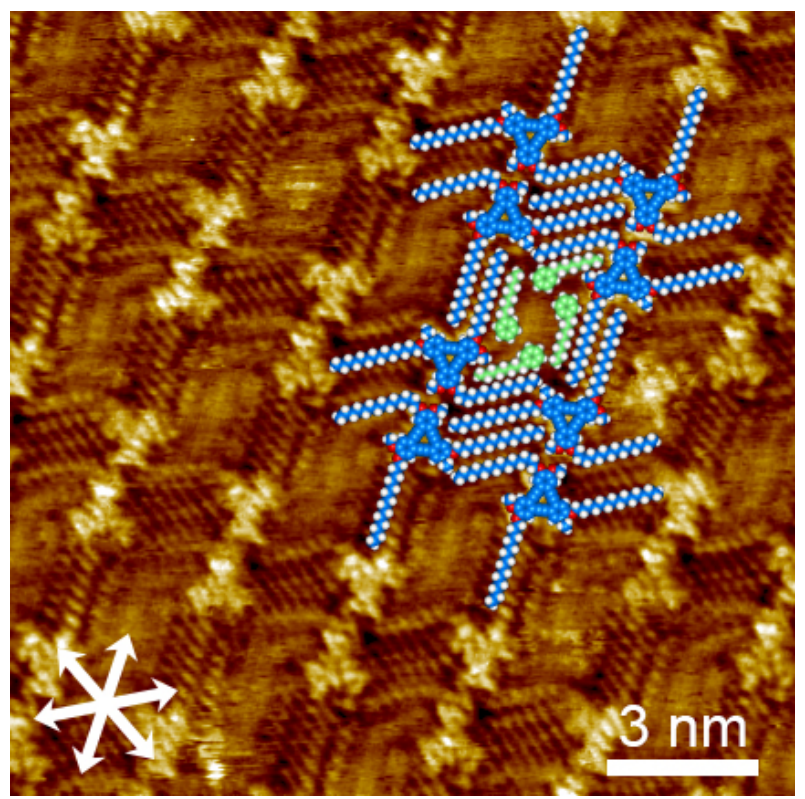

Figure S4. STM images of a parallelogram structure formed by DBA-OC14-OC1 at the PO/graphite interface $\left(1 \times 10^{-6} \mathrm{M}\right)$. The image includes molecular models. The carbon atoms of DBA molecules and four co-adsorbed PO molecules at the parallelogram pore are colored in blue and light green, respectively. This STM image is identical to Figure $4 \mathrm{a}$ of the main text.



Figure S5. STM images of a hexagonal B structure formed by DBA-OC14-OC1 at the PO/graphite interface $\left(1 \times 10^{-6} \mathrm{M}\right)$. The image includes molecular models. The carbon atoms of DBA molecules and two co-adsorbed PO molecules are colored in a blue and light green, respectively. This STM image is identical to Figure $4 c$ of the main text. 




Figure S6. STM images of a dense-linear structure formed by DBA-OC14-OC1 at the PO/graphite interface $\left(5 \times 10^{-5} \mathrm{M}\right)$. The image includes molecular models. The carbon atoms of DBA molecules and a co-adsorbed PO molecule are colored in a blue and light green, respectively. This STM image is identical to Figure $4 \mathrm{e}$ of the main text. 


\section{Details on MM Simulations.}

In the modeling of network structures in PO, co-adsorbed solvent molecules are included according to the STM image analyses (Figures S4-S6). For the hexagonal B structure, we modeled two structures with different numbers of co-adsorbed PO molecules (two or five molecules). In the case of TCB, we assume that the pore spaces are occupied by the maximum number of TCB molecules. ${ }^{4}$ The initial alignments of co-adsorbed TCB molecules at the pores were constructed using the following procedure. First, the maximum number of TCB molecules are included in the pore. Then each TCB molecule is laterally rotated taking favorable $\mathrm{C}-\mathrm{H} \cdots \mathrm{Cl}-\mathrm{C}$ and $\mathrm{C}-\mathrm{Cl} \cdots \mathrm{Cl}-\mathrm{C}$ interactions into account. ${ }^{5}$ In the case of the honeycomb structure of DBA-OC14-OC1, twelve TCB molecules are placed along the rims of the hexagonal pore, as several bright features are observed at those positions in the STM image (Figure 2a). This is also supported by a honeycomb structure formed by a closely related molecule, DBA-OC14-OMOM, a synthetic intermediate of DBA-OC14OC1, where at least twelve co-adsorbed TCB molecules were observed along the rims of the hexagonal pores (Figure S1). Then central part of the pores is occupied by TCB molecules. In addition to the DBA-OC14-OC1 networks, the models of the honeycomb and linear structures of DBA-OC14 were optimized for comparison, and starting geometries are built according to the previous report. ${ }^{6}$

Figures 6-8 show optimized geometries of the six observed network structures of DBA-OC14OC1 and the two monolayer structures of DBA-OC14. 


\section{Energy Estimations for Monolayer Networks by MM Simulations.}

In order to determine the energy changes per single molecule, the results of the MM simulations were analyzed by a procedure which modified the previously reported methods by Gutzler $e t a l^{7}$ and by us. ${ }^{6}$ Table S1 summarizes each energy value.

1. Energy changes upon adsorption of a single DBA molecule from vacuum to a monolayer without including solvent molecules $\left(\Delta e_{\text {total-single }}\right)$

-Energy after optimizations of a monolayer network on bi-layered graphite sheets: $e_{1}$

-Energy after single point calculations after removal of one DBA molecule from the optimized network structures of the DBA molecules on bi-layered graphite sheets: $e_{2}$

-Energy of an optimized geometry of a single DBA molecule under vacuum: $e_{3}$

$\Delta e_{\text {total-single }}=e_{1}-\left(e_{2}+e_{3}\right)$

2. Interaction energy between a DBA molecule and substrate $\left(\Delta e_{\text {mol-sub-single }}\right)$ and between DBA molecules $\left(\Delta e_{\text {mol-mol-single }}\right)$ upon adsorption of a single DBA molecule in a monolayer without including solvent molecules

- Energy after single point calculations of a single DBA molecule having identical geometry with that of the optimized monolayer network on the bi-layered graphite sheets: $e_{4}$

$\Delta e_{\text {mol-sub-single }}=e_{4}-e_{3}$

$\Delta e_{\text {mol-mol-single }}=\left(\Delta e_{\text {total-single }}-\Delta e_{\text {mol-sub-single }}\right) /($ number of the DBA molecules per a unit cell $)$

3. Enthalpy change upon adsorption of a single DBA molecule from vacuum to the monolayer network without including solvent molecules $\left(\Delta h_{\text {DBA-single }}\right)$

$\Delta h_{\mathrm{DBA}-\text { single }}=\Delta e_{\mathrm{mol}-\mathrm{mol} \text {-single }}+\Delta e_{\mathrm{mol}-\text { sub-single }}$

4. Enthalpy changes upon adsorption of solvent molecules from vacuum to a monolayer network including solvent molecules $\left(\Delta h_{\text {solv-pore }}\right)$

-Positions and orientations of the solvent molecules in the initial geometries were chosen as described in section 5 .

·Energy after optimization of a monolayer network including solvent molecules: $e_{5}$

-Energy of an optimized geometry of a single solvent molecule under vacuum: $e_{6}$ $\Delta h_{\text {solv-pore }}=e_{5}-\left((\right.$ number of the co-adsorbed solvent molecules per a unit cell $\left.) \times e_{6}+e_{1}\right)$ 
5. Since the number of the DBA molecules and unit areas are different among the observed network structures, the energy values ( $\Delta e_{\text {mol-mol-single }}, \Delta e_{\text {mol-sub-single, }}$ and $\left.\Delta h_{\mathrm{DBA}-\text { single }}\right)$ are multiplied by the number DBA molecules per unit cell. Then, the calculated energy values and $\Delta h_{\text {solv-pore value are }}$ divided by unit area $(A)$ to afford $\Delta e_{\text {mol-mol, }} \Delta e_{\text {mol-sub }}, \Delta h_{\mathrm{DBA}}$ and $\Delta h_{\text {solv }}$ as summarized in Table 2 . The $\Delta h$ values are calculated using the following equation.

$\Delta h=\Delta h_{\mathrm{DBA}}+\Delta h_{\mathrm{solv}}$

Table S1. Estimated Energies $\left(\mathrm{kcal} \cdot \mathrm{mol}^{-1}\right)$ of Self-Assembled Structures Formed by DBA-OC14OC1.

\begin{tabular}{|c|c|c|c|c|c|c|c|}
\hline solvent & \multicolumn{3}{|c|}{ TCB } & \multicolumn{3}{c|}{ PO } \\
\hline $\begin{array}{c}\text { monolayer } \\
\text { structure }\end{array}$ & $\begin{array}{c}\text { honeycomb } \\
\text { structure }\end{array}$ & $\begin{array}{c}\text { parallelo } \\
\text { gram } \\
\text { structure }\end{array}$ & $\begin{array}{c}\text { hexagonal } \\
\text { A structure }\end{array}$ & $\begin{array}{c}\text { parallelogr } \\
\text { am } \\
\text { structure }\end{array}$ & $\begin{array}{c}\text { hexagonal B } \\
\text { structure }\end{array}$ & $\begin{array}{c}\text { dense- } \\
\text { linear } \\
\text { structure }\end{array}$ \\
\hline $\begin{array}{c}\text { number of } \\
\text { DBA } \\
\text { molecules }\end{array}$ & 2 & 2 & 6 & 2 & & \\
\hline $\begin{array}{c}\text { number of } \\
\text { solvent } \\
\text { molecules }\end{array}$ & 23 & 6 & 26 & 4 & 2 & 5 & 2 \\
\hline$e_{1}$ & -398.6 & -400.3 & -1225.0 & -405.4 & -1128.3 & -1070.3 & -301.3 \\
\hline$e_{2}$ & -182.2 & -187.1 & -999.6 & -187.6 & -908.3 & -887.4 & -135.4 \\
\hline$e_{3}$ & -38.9 & -38.9 & -38.9 & -38.9 & -38.9 & -38.9 & -38.9 \\
\hline$e_{4}$ & -182.2 & -187.1 & -182.8 & -187.6 & -169.0 & -163.3 & -139.0 \\
\hline$\Delta e_{\text {total-single }}$ & -177.4 & -174.2 & -186.4 & -178.8 & -181.1 & -164.9 & -127.0 \\
\hline$\Delta e_{\text {mol-sub-single }}$ & -143.3 & -148.2 & -143.8 & -148.7 & -130.1 & -117.6 & -100.1 \\
\hline$\Delta e_{\text {mol-mol-single }}$ & -17.1 & -13.0 & -7.1 & -15.1 & -8.5 & -7.9 & -13.5 \\
\hline$\Delta h_{\text {DBA-single }}$ & -160.4 & -161.2 & -150.9 & -163.8 & -138.6 & -125.5 & -113.6 \\
\hline$e_{5}$ & -889.9 & -536.7 & -1792.1 & -625.7 & -1245.1 & -1377.2 & -349.0 \\
\hline$e_{6}$ & 3.4 & 3.4 & 3.4 & -19.0 & -19.0 & -19.0 & -19.0 \\
\hline$\Delta h_{\text {solv-pore }}$ & -568.7 & -156.7 & -654.7 & -144.3 & -78.7 & -211.9 & -28.7 \\
\hline
\end{tabular}




\section{Estimations of Entropy Changes upon Desorption of DBA and Solvent Molecules.}

Averaged van der Waals volumes of the DBA-OC14, DBA-OC14-OC1 and solvent molecules are estimated by DFT calculations (B3LYP/6-31G(d)) using the Gaussian 16 program package to be 2246.4, 1414.4, 188.2 and $306.7 \AA^{3}$ for optimized geometries of DBA-OC14 ( $D_{3 h}$ symmetry), DBAOC14-OC1 ( $C_{3 h}$ symmetry), TCB ( $C_{\mathrm{s}}$ symmetry) and PO ( $C_{\mathrm{s}}$ symmetry), respectively. ${ }^{8}$

The total entropy gain upon desorption of a molecule from a network is divided into four separate contributions from different types of motion; translational, rotational, vibrational and conformational.

$$
\Delta S_{\text {total }}=\Delta S_{\text {vib }}+\Delta S_{\text {con }}+\Delta S_{\text {trans }}+\Delta S_{\text {rot }}
$$

$\Delta S_{\text {total }}$ : Total entropy change

$\Delta S_{\text {trans }}$ : Translational entropy change

$\Delta S_{\text {rot }}$ : Rotational entropy change

$\Delta S_{\text {vib: }}$ Vibrational entropy change

$\Delta S_{\text {con }}$ : Conformational entropy change

Estimation of these contributions to the total entropy has been documented by G. Whitesides and co-workers. ${ }^{9,10}$

\section{$\Delta S_{\text {vib: }}$ Vibrational entropy change.}

Most molecular vibrations will make a very small contribution to the total entropy change. In addition, the high frequency and small amplitude of molecular vibrations are probably largely unaffected by incorporation into self-assembled networks. For these reasons the contribution from the vibrational entropy was ignored $\Delta S_{\mathrm{vib}} \approx 0$.

\section{$\Delta S_{\text {con }}$ : Conformational entropy change.}

Any molecules having flexible parts lose conformational entropy when confined on the surface. Using the Whitesides' method, ${ }^{9}$ the torsional entropies of a variety of bonds of common organic compounds could be estimated. The total conformational entropy of a molecule is calculated by counting the numbers of relevant bonds in the molecular system and adding together their torsional entropies.

For the DBA-OC14 and DBA-OC14-OC1 molecules, none of the bonds within the annulene core contribute to the conformational entropy as they are rigid and incapable of rotation. Therefore, the conformational entropy of each OC14 alkoxy chain is calculated as the sum of the torsional entropies of the $\mathrm{C}-\mathrm{O}$ bond between the annulene core and the $\mathrm{O}$ atom of the alkoxy chain, the $\mathrm{O}-\mathrm{C}$ bond between the $\mathrm{O}$ atom of the alkoxy group and the $\mathrm{CH}_{2}$ group adjacent to it, $12 \mathrm{C}$ - $\mathrm{C}$ bonds between adjacent 
$\mathrm{CH}_{2}$ groups, and one $\mathrm{C}-\mathrm{C}$ bond between the penultimate $\mathrm{CH}_{2}$ group and the terminal $\mathrm{CH}_{3}$ group of the chain.

$$
\Delta S_{\text {DBA-OC14-chain-con }}=12.2+6.1+(6.5 \times 12)+7.1=103.4\left(\mathrm{~J} \cdot \mathrm{K}^{-1} \cdot \mathrm{mol}^{-1}\right)
$$

Similarly, the conformational entropy of one methoxy group is calculated as the sum of the torsional entropies of the $\mathrm{C}-\mathrm{O}$ bond between the annulene core and the $\mathrm{O}$ atom of the alkoxy chain, and the $\mathrm{O}-\mathrm{C}$ bond between the $\mathrm{O}$ atom of the alkoxy group and the $\mathrm{CH}_{3}$ group.

$$
\Delta \mathrm{S}_{\text {DBA-OC1-group-con }}=12.2+6.1=18.3\left(\mathrm{~J} \cdot \mathrm{K}^{-1} \cdot \mathrm{mol}^{-1}\right)
$$

We assume that the alkoxy chains and methoxy groups of the DBA molecule loose all of their conformational entropies upon adsorption. Then we multiply this value by the number of adsorbed alkoxy chains (x) and methoxy groups (y) per single DBA molecule. The estimate for the conformational entropy change of a DBA molecule released from the respective network into the solution is therefore given by

$$
\begin{gathered}
\Delta S_{\text {DBA-OC14-OC1-con }}=3 \times \Delta S_{\text {DBA-OC14-chain-con }}-\mathrm{x} \times\left(\Delta S_{\text {DBA-OC14-chain-con }}-8.31 \times \ln 2\right) \\
+3 \times \Delta S_{\text {DBA-OC1-group-con }}-\mathrm{y} \times\left(\Delta S_{\text {DBA-OC1-group-con }}-8.31 \times \ln 2\right) \\
\Delta S_{\text {DBA-OC14-con }}=6 \times \Delta S_{\text {DBA-OC14-chain-con }}-\mathrm{x} \times\left(\Delta S_{\text {DBA-OC14-chain-con }}-8.31 \times \ln 2\right)
\end{gathered}
$$

The estimated conformational entropy changes are summarized in Tables S2 and S3.

In the case of TCB, none of the bonds are capable of rotation, therefore TCB shows no change in conformational entropy upon desorption. On the other hand, change of the conformational entropy of PO which has a flexible alky chain can be calculated.

$$
\begin{gathered}
\Delta S_{\mathrm{TCB}-\mathrm{con}} \approx 0\left(\mathrm{~J} \cdot \mathrm{K}^{-1} \cdot \mathrm{mol}^{-1}\right) \\
\Delta S_{\mathrm{PO}-\text { con }}=12.2+(6.5 \times 6)+7.1=58.3\left(\mathrm{~J} \cdot \mathrm{K}^{-1} \cdot \mathrm{mol}^{-1}\right)
\end{gathered}
$$


Table S2. Estimated Conformational Entropy Changes of DBA-OC14-OC1 by Desorption from Different Structures.

\begin{tabular}{|c|c|c|c|c|c|}
\hline & $\begin{array}{c}\text { honeycomb } \\
\text { structure }\end{array}$ & $\begin{array}{c}\text { parallelogra } \\
\text { m structure }\end{array}$ & $\begin{array}{c}\text { hexagonal } \\
\text { A }\end{array}$ & $\begin{array}{c}\text { hexagonal } \\
\text { B }\end{array}$ & $\begin{array}{c}\text { dense-linear } \\
\text { structure }\end{array}$ \\
\hline $\begin{array}{c}\text { number of } \\
\text { absorbed OC14 } \\
\text { chains }^{a}\end{array}$ & 3 & 3 & 3 & 2 & 1 \\
\hline $\begin{array}{c}\text { number of } \\
\text { absorbed methoxy } \\
\text { groups }^{a}\end{array}$ & 3 & 3 & 2 & 3 & 3 \\
\hline $\begin{array}{c}\Delta S_{\text {con }^{-1}} \\
\left(\mathrm{JK}^{-1} \cdot \mathrm{mol}^{-1}\right)\end{array}$ & 365.1 & 365.1 & 352.6 & 267.5 & 169.8 \\
\hline
\end{tabular}

${ }^{a}$ Number of the adsorbed chain or methoxy groups are determined using MM optimized geometries.

Table S3. Estimated Conformational Entropy Changes of DBA-OC14 by Desorption from Honeycomb and Linear Structures.

\begin{tabular}{|c|c|c|}
\hline $\begin{array}{c}\text { number of } \\
\text { absorbed OC14 } \\
\text { chains }\end{array}$ & $\begin{array}{c}\text { honeycomb } \\
\text { structure }\end{array}$ & linear structure \\
\hline $\begin{array}{c}\Delta S_{\text {con }} \\
\left(\mathrm{J} \cdot \mathrm{K}^{-1} \cdot \mathrm{mol}^{-1}\right)\end{array}$ & 6 & 4,5 \\
\hline
\end{tabular}

${ }^{a}$ Number of the adsorbed chain or methoxy groups are determined using MM optimized geometries. 


\section{$\Delta S_{\text {trans }}$ : Translational entropy change.}

We assume no translational entropy for a molecule adsorbed on the surface. Hence, the translational entropy of a DBA or solvent molecule is calculated in a dilute solution. The translational entropy can be calculated using the following equation. ${ }^{7,9}$

$$
\Delta S_{\text {trans }}=R \ln \left[\left(\frac{10^{-\frac{15}{2}}}{N_{\mathrm{A}}^{4}[\mathrm{X}]}\right)\left(\frac{2 \pi M R T e^{\frac{5}{3}}}{h^{2}}\right)^{\frac{3}{2}}\right]
$$

$R$ : gas constant: $8.31\left(\mathrm{~J} \cdot \mathrm{K}^{-1} \cdot \mathrm{mol}^{-1}\right)$

$N_{\mathrm{A}}$ : Avogadro number $\left(\mathrm{mol}^{-1}\right)$

$M$ : molecular weight $\left(\mathrm{g} \cdot \mathrm{mol}^{-1}\right)$

$T$ : temperature $(297 \mathrm{~K})$

$h$ : Planck constant $\left(\mathrm{m}^{2} \cdot \mathrm{kg} \cdot \mathrm{s}^{-1}\right)$

$[\mathrm{X}]$ : concentration after recalculation taking the free volume of the solvent into account $\left(\mathrm{mol} \cdot \mathrm{L}^{-1}\right)$

In order to obtain accurate values for molecules in solution, the concentration needs to be recalculated in terms of the free volume of the solvent according to a method reported by Whitesides and co-workers. ${ }^{9}$ The solvent free volume, concentration [X], and $\Delta S_{\text {trans }}$ values are summarized in Table S4. Moreover, calculated concentrations $[\mathrm{X}]$ and estimated $\Delta S_{\text {trans }}$ values of DBA-OC14-OC1 and DBA-OC14 are summarized in Tables S5-S7.

Table S4. Solvent Free Volume, Concentration [X], and Translational Entropy $\Delta S_{\text {trans }}$ Values.

\begin{tabular}{|c|c|c|}
\hline & TCB & PO \\
\hline free volume $(\mathrm{mL})$ & 0.22 & 1.6 \\
\hline$[\mathrm{X}]\left(\mathrm{mol} \cdot \mathrm{L}^{-1}\right)$ & $3.66 \times 10^{4}$ & $2.82 \times 10^{3}$ \\
\hline$\Delta S_{\text {trans }}\left(\mathrm{J} \cdot \mathrm{K}^{-1} \cdot \mathrm{mol}^{-1}\right)$ & 59.6 & 81.5 \\
\hline
\end{tabular}

Table S5. Translational Entropy Changes of DBA-OC14-OC1 in TCB at Three Different Concentrations.

\begin{tabular}{|c|c|c|}
\hline${\text { concentration }(\mathrm{M})^{a}}^{a}$ & {$[\mathrm{X}]\left(\mathrm{mol} \cdot \mathrm{L}^{-1}\right)$} & $\Delta S_{\text {trans }}(\mathrm{J} /(\mathrm{K} \cdot \mathrm{mol}))$ \\
\hline $3 \times 10^{-6}$ & $1 \times 10^{-2}$ & 204.2 \\
\hline $6 \times 10^{-5}$ & $3 \times 10^{-1}$ & 179.3 \\
\hline $7 \times 10^{-4}$ & 3 & 158.9 \\
\hline
\end{tabular}

${ }^{a}$ These concentrations were employed experimentally. 
Table S6. Translational Entropy Changes of DBA-OC14-OC1 in PO at Three Different Concentrations.

\begin{tabular}{|c|c|c|}
\hline concentration $(\mathrm{M})^{a}$ & {$[\mathrm{X}]\left(\mathrm{mol} \cdot \mathrm{L}^{-1}\right)$} & $\Delta S_{\text {trans }}(\mathrm{J} /(\mathrm{K} \cdot \mathrm{mol}))$ \\
\hline $1 \times 10^{-6}$ & $6 \times 10^{-4}$ & 229.8 \\
\hline $3 \times 10^{-6}$ & $2 \times 10^{-3}$ & 220.7 \\
\hline $5 \times 10^{-5}$ & $3 \times 10^{-2}$ & 197.3 \\
\hline
\end{tabular}

${ }^{a}$ These concentrations were employed experimentally.

Table S7. Translational Entropy Changes of DBA-OC14 in TCB at Three Different Concentrations.

\begin{tabular}{|c|c|c|}
\hline concentration $(\mathrm{M})^{a}$ & {$[\mathrm{X}]\left(\mathrm{mol} \cdot \mathrm{L}^{-1}\right)$} & $\Delta S_{\text {trans }}(\mathrm{J} /(\mathrm{K} \cdot \mathrm{mol}))$ \\
\hline $3 \times 10^{-6}$ & $1 \times 10^{-2}$ & 209.5 \\
\hline $6 \times 10^{-5}$ & $3 \times 10^{-1}$ & 184.6 \\
\hline $7 \times 10^{-4}$ & 3 & 164.2 \\
\hline
\end{tabular}

${ }^{a}$ These concentrations were employed experimentally.

\section{$\Delta \mathrm{S}_{\text {rot }}$ : Rotational entropy change.}

The rotational entropy is considered to be zero for a surface confined molecule, and therefore the entropy change should be equal to the entropy in solution. The rotational entropy in solution can be calculated using the following equation. ${ }^{7,9}$ Calculated moments of inertia and rotational entropy changes are summarized in Table S8.

$$
\Delta S_{\text {rot }}=R \ln \left[\pi^{\frac{1}{2}}\left(\frac{8 \pi^{2} R T e}{h^{2} N_{\mathrm{A}}}\right)^{\frac{3}{2}}\left(I_{\text {sphere }}\right)^{\frac{3}{2}}\right]
$$

$I_{\text {sphere: }}$ moment of inertia $\left(\mathrm{kg} \cdot \mathrm{m}^{2}\right)$

Table S8. Rotational Entropy Changes of DBAs and Solvent Molecules.

\begin{tabular}{|c|c|c|c|c|}
\hline & DBA-OC14-OC1 & DBA-OC14 & TCB & PO \\
\hline$I_{\text {sphere }}\left(\mathrm{kg} \cdot \mathrm{m}^{2}\right)$ & $3.31 \times 10^{-43}$ & $6.90 \times 10^{-43}$ & $1.52 \times 10^{-44}$ & $2.21 \times 10^{-44}$ \\
\hline$\Delta S_{\text {rot }}\left(\mathrm{J} \cdot \mathrm{K}^{-1} \cdot \mathrm{mol}^{-1}\right)$ & 171.8 & 181.0 & 133.5 & 138.1 \\
\hline
\end{tabular}




\section{$\Delta \mathrm{S}_{\text {total }}$ : Total entropy change.}

Calculated entropy changes are summarized in Tables S9-S12. By increasing DBA concentrations, total entropy changes increase. There are small differences between TCB and PO, by comparison of $\Delta S_{\text {total }}$ values of the parallelogram structures observed in both solvents $\left(52.6\right.$ and $53.8 \mathrm{kcal} \cdot \mathrm{mol}^{-1}$ in TCB and PO) at identical concentration $\left(3 \times 10^{-6}\right)$. Note that the overall entropy changes for DBAOC14 are larger than those for DBA-OC14-OC1 in all cases because of the larger number of adsorbed chains.

Table S9. Total Entropy Changes of DBA-OC14-OC1 by Desorption from Different Structures Observed in TCB.

\begin{tabular}{|c|c|c|c|c|c|c|c|c|c|}
\hline & \multicolumn{2}{|c|}{ honeycomb structure } & \multicolumn{2}{c|}{ parallelogram structure } & \multicolumn{3}{|c|}{ hexagonal A structure } \\
\hline $\begin{array}{c}\text { concentration } \\
(\mathrm{M})\end{array}$ & $3 \times$ & $6 \times$ & $7 \times$ & $3 \times$ & $6 \times$ & $7 \times$ & $3 \times$ & $6 \times$ & $7 \times$ \\
\hline $\begin{array}{c}\Delta S_{\text {total }}^{-6} \\
\left(\mathrm{~J} \cdot \mathrm{K}^{-1} \cdot \mathrm{mol}^{-1}\right)\end{array}$ & 741.1 & 716.2 & 695.8 & 741.1 & 716.2 & 695.8 & 728.6 & 703.7 & 683.3 \\
\hline $\begin{array}{c}T \Delta S_{297} \\
\left(\mathrm{kcal} \cdot \mathrm{mol}^{-1}\right)\end{array}$ & 52.6 & 50.8 & 49.4 & 52.6 & 50.8 & 49.4 & 51.7 & 50.0 & 48.5 \\
\hline $\begin{array}{c}T \Delta S_{297} \mathrm{per}^{-4} \\
\mathrm{unit} \text { area } \\
\left(\mathrm{kcal} \cdot \mathrm{mol}^{-}\right. \\
\left.1 \cdot \mathrm{nm}^{-2}\right)\end{array}$ & 5.0 & 4.9 & 4.7 & 8.7 & 8.4 & 8.1 & 7.8 & 7.5 & 7.3 \\
\hline
\end{tabular}

Table S10. Total Entropy Changes of DBA-OC14-OC1 by Desorption from Different Structures Observed in PO.

\begin{tabular}{|c|c|c|c|c|c|c|c|c|c|}
\hline & \multicolumn{3}{|c|}{ parallelogram structure } & \multicolumn{2}{c|}{ hexagonal B structure } & \multicolumn{3}{c|}{ dense-linear structure } \\
\hline $\begin{array}{c}\text { concentration } \\
(\mathrm{M})\end{array}$ & $\begin{array}{c}1 \times \\
10^{-6}\end{array}$ & $\begin{array}{c}3 \times \\
10^{-6}\end{array}$ & $\begin{array}{c}5 \times \\
10^{-5}\end{array}$ & $\begin{array}{c}1 \times \\
10^{-6}\end{array}$ & $\begin{array}{c}3 \times \\
10^{-6}\end{array}$ & $\begin{array}{c}5 \times \\
10^{-5}\end{array}$ & $\begin{array}{c}1 \times \\
10^{-6}\end{array}$ & $\begin{array}{c}3 \times \\
10^{-6}\end{array}$ & $\begin{array}{c}5 \times \\
10^{-5}\end{array}$ \\
\hline $\begin{array}{c}\Delta S_{\text {total }} \\
\left(\mathrm{J} \cdot \mathrm{K}^{-1} \cdot \mathrm{mol}^{-1}\right)\end{array}$ & 766.8 & 757.6 & 734.3 & 669.1 & 660.0 & 636.6 & 571.5 & 562.4 & 539.0 \\
\hline $\begin{array}{c}T \Delta S_{297} \\
\left(\mathrm{kcal} \cdot \mathrm{mol}^{-1}\right)\end{array}$ & 54.4 & 53.8 & 52.1 & 47.5 & 46.8 & 45.2 & 40.6 & 39.9 & 38.3 \\
\hline $\begin{array}{c}T \Delta S_{297} \mathrm{per}^{\mathrm{unit} \text { area }} \\
\left(\mathrm{kcal} \cdot \mathrm{mol}^{-}\right. \\
\left.1 \cdot \mathrm{nm}^{-2}\right)\end{array}$ & 9.4 & 9.3 & 9.0 & 10.6 & 10.5 & 10.1 & 13.5 & 13.3 & 12.7 \\
\hline
\end{tabular}


Table S11. Total Entropy Changes of DBA-OC14 by Desorption from Different Structures Observed in TCB.

\begin{tabular}{|c|c|c|c|c|c|c|}
\hline & \multicolumn{3}{|c|}{ honeycomb structure } & \multicolumn{3}{c|}{ linear structure } \\
\hline $\begin{array}{c}\text { concentration } \\
(\mathrm{M})\end{array}$ & $3 \times 10^{-6}$ & $6 \times 10^{-5}$ & $7 \times 10^{-4}$ & $3 \times 10^{-6}$ & $6 \times 10^{-5}$ & $7 \times 10^{-4}$ \\
\hline $\begin{array}{c}\Delta S_{\text {total }} \\
\left(\mathrm{J} \cdot \mathrm{K}^{-1} \cdot \mathrm{mol}^{-1}\right)\end{array}$ & 1010.9 & 986.0 & 965.6 & 864.5 & 839.6 & 819.2 \\
\hline $\begin{array}{c}T \Delta S_{297}\left(\mathrm{kcal} \cdot \mathrm{mol}^{-}\right. \\
1\end{array}$ & 71.8 & 70.0 & 68.5 & 61.4 & 59.6 & 58.1 \\
\hline $\begin{array}{c}T \Delta S_{297} \mathrm{per} \text { unit } \\
\text { area } \\
\left(\mathrm{kcal} \cdot \mathrm{mol}^{-1} \cdot \mathrm{nm}^{-2}\right)\end{array}$ & 6.7 & 6.5 & 6.4 & 10.5 & 10.2 & 10.0 \\
\hline
\end{tabular}

Because of the contributions from $\Delta S_{\text {con }}$ and $\Delta S_{\text {trans, }}$, the total entropy changes for PO is larger than that of TCB.

Table S12. Total Entropy Changes of the Solvent Molecules.

\begin{tabular}{|c|c|c|}
\hline compound & TCB & PO \\
\hline$\Delta S_{\text {vib }}\left(\mathrm{J} \cdot \mathrm{K}^{-1} \cdot \mathrm{mol}^{-1}\right)$ & 0 & 0 \\
\hline$\Delta S_{\text {con }}\left(\mathrm{J} \cdot \mathrm{K}^{-1} \cdot \mathrm{mol}^{-1}\right)$ & 0 & 58.3 \\
\hline$\Delta S_{\text {trans }}\left(\mathrm{J} \cdot \mathrm{K}^{-1} \cdot \mathrm{mol}^{-1}\right)$ & 59.6 & 81.5 \\
\hline$\Delta S_{\text {rot }}\left(\mathrm{J} \cdot \mathrm{K}^{-1} \cdot \mathrm{mol}^{-1}\right)$ & 133.5 & 138.1 \\
\hline$\Delta S_{\text {tot }}\left(\mathrm{J} \cdot \mathrm{K}^{-1} \cdot \mathrm{mol}^{-1}\right)$ & 193.1 & 277.9 \\
\hline$T \Delta S_{297}\left(\mathrm{kcal} \cdot \mathrm{mol}^{-1}\right)$ & 13.7 & 19.7 \\
\hline
\end{tabular}


7. ${ }^{1} \mathrm{H}$ and ${ }^{13} \mathrm{C}$ Spectra of DBA-OC14-OC1.
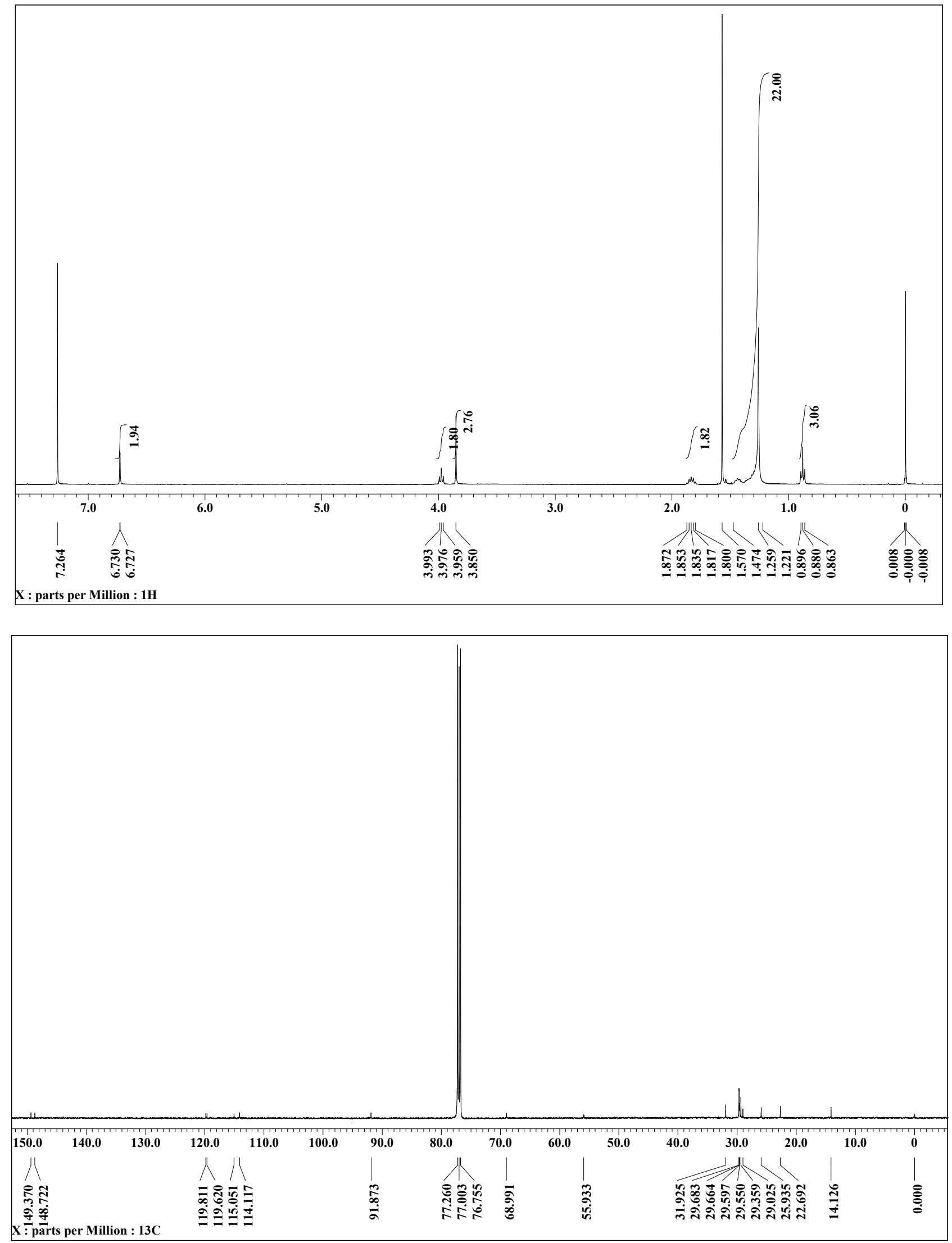

Figure S7. ${ }^{1} \mathrm{H}$ (top) and ${ }^{13} \mathrm{C}$ (bottom) NMR spectra of DBA-OC14-OC1 in $\mathrm{CDCl}_{3}$. 


\section{Cartesian Coordinates of Optimized Geometries.}

\section{Geometry I- $C_{3} h$-anti}

Zero-point correction $=$

1.567059 (Hartree/Particle)

Thermal correction to Energy=

1.655690

Thermal correction to Enthalpy=

1.656635

Thermal correction to Gibbs Free Energy=

1.415047

Sum of electronic and zero-point Energies $=$

$-3141.249283$

Sum of electronic and thermal Energies=

$-3141.160652$

Sum of electronic and thermal Enthalpies=

$-3141.159708$

Sum of electronic and thermal Free Energies=

$-3141.401295$

Standard orientation:

\begin{tabular}{|c|c|c|c|c|c|}
\hline \multirow{2}{*}{$\begin{array}{l}\text { Center } \\
\text { Number }\end{array}$} & \multirow{2}{*}{$\begin{array}{l}\text { Atomic } \\
\text { Number }\end{array}$} & \multirow{2}{*}{$\begin{array}{l}\text { Atomic } \\
\text { Type }\end{array}$} & \multicolumn{3}{|c|}{ Coordinates (Angstroms) } \\
\hline & & & $\mathrm{X}$ & $\mathrm{Y}$ & $\mathrm{Z}$ \\
\hline 1 & 6 & 0 & 1.366427 & 2.483850 & 0.000000 \\
\hline 2 & 6 & 0 & 2.396542 & 1.515983 & 0.000000 \\
\hline 3 & 6 & 0 & 3.738297 & 1.946760 & 0.000000 \\
\hline 4 & 6 & 0 & 4.071914 & 3.292978 & 0.000000 \\
\hline 5 & 6 & 0 & 3.037060 & 4.264280 & 0.000000 \\
\hline 6 & 6 & 0 & 1.714181 & 3.849480 & 0.000000 \\
\hline 7 & 1 & 0 & 4.512907 & 1.193657 & 0.000000 \\
\hline 8 & 1 & 0 & 0.914380 & 4.575980 & 0.000000 \\
\hline 9 & 6 & 0 & 0.000000 & 2.099588 & 0.000000 \\
\hline 10 & 6 & 0 & -1.159675 & 1.751663 & 0.000000 \\
\hline 11 & 6 & 0 & 2.096822 & 0.128477 & 0.000000 \\
\hline 12 & 6 & 0 & 1.818297 & -1.049794 & 0.000000 \\
\hline 13 & 6 & 0 & -2.511151 & 1.317475 & 0.000000 \\
\hline 14 & 6 & 0 & -2.834291 & -0.058564 & 0.000000 \\
\hline 15 & 6 & 0 & -3.555092 & 2.264080 & 0.000000 \\
\hline 16 & 6 & 0 & -4.190838 & -0.440216 & 0.000000 \\
\hline 17 & 6 & 0 & -4.887760 & 1.879892 & 0.000000 \\
\hline 18 & 1 & 0 & -3.290191 & 3.311464 & 0.000000 \\
\hline 19 & 6 & 0 & -5.211505 & 0.498031 & 0.000000 \\
\hline 20 & 1 & 0 & -4.420105 & -1.496114 & 0.000000 \\
\hline 21 & 6 & 0 & 1.467864 & -2.425285 & 0.000000 \\
\hline 22 & 6 & 0 & 2.476657 & -3.409264 & 0.000000 \\
\hline
\end{tabular}




6

26

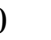

31

$$
\begin{array}{ccc}
0.114609 & -2.833458 & 0.000000 \\
2.174445 & -4.762311 & 0.000000 \\
3.505725 & -3.079866 & 0.000000 \\
-0.183205 & -4.210840 & 0.000000 \\
0.815846 & -5.172870 & 0.000000 \\
-1.222716 & -4.505121 & 0.000000 \\
-1.818297 & -1.049794 & 0.000000 \\
-0.937147 & -1.880139 & 0.000000 \\
0.608399 & -6.513756 & 0.000000 \\
3.089896 & -5.765812 & 0.000000 \\
5.336879 & 3.783767 & 0.000000 \\
3.448392 & 5.558834 & 0.000000 \\
-5.945278 & 2.729989 & 0.000000 \\
-6.538288 & 0.206978 & 0.000000 \\
6.433286 & 2.868037 & 0.000000 \\
6.381331 & 2.225421 & 0.888573 \\
6.381331 & 2.225421 & -0.888573 \\
-5.700436 & 4.137371 & 0.000000 \\
-5.117937 & 4.413684 & 0.888573 \\
-5.117937 & 4.413684 & -0.888573 \\
-0.732850 & -7.005408 & 0.000000 \\
-1.263394 & -6.639105 & 0.888573 \\
-1.263394 & -6.639105 & -0.888573 \\
7.713944 & 3.687257 & 0.000000 \\
7.707824 & 4.340888 & -0.878390 \\
7.707824 & 4.340888 & 0.878390 \\
-0.663714 & -8.524100 & 0.000000 \\
-0.094593 & -8.845615 & 0.878390 \\
-0.094593 & -8.845615 & -0.878390 \\
-7.050230 & 4.836843 & 0.000000 \\
-7.613231 & 4.504727 & 0.878390 \\
-7.613231 & 4.504727 & -0.878390 \\
8.973328 & 2.813834 & 0.000000 \\
8.962659 & 2.154586 & -0.877449 \\
8.962659 & 2.154586 & 0.877449 \\
-2.649812 & -9.178047 & 0.000000 \\
-6.83516 & 6.364213 & 0.000000
\end{array}
$$




\begin{tabular}{|c|c|c|c|c|c|}
\hline 62 & 1 & 0 & -6.347256 & 6.684597 & 0.877449 \\
\hline 63 & 1 & 0 & -6.347256 & 6.684597 & -0.877449 \\
\hline 64 & 6 & 0 & 10.271180 & 3.629888 & 0.000000 \\
\hline 65 & 1 & 0 & 10.281930 & 4.289687 & 0.876737 \\
\hline 66 & 1 & 0 & 10.281930 & 4.289687 & -0.876737 \\
\hline 67 & 6 & 0 & -1.992015 & -10.710047 & 0.000000 \\
\hline 68 & 1 & 0 & -1.425987 & -11.049256 & 0.876737 \\
\hline 69 & 1 & 0 & -1.425987 & -11.049256 & -0.876737 \\
\hline 70 & 6 & 0 & -8.279165 & 7.080159 & 0.000000 \\
\hline 71 & 1 & 0 & -8.855943 & 6.759569 & 0.876737 \\
\hline 72 & 1 & 0 & -8.855943 & 6.759569 & -0.876737 \\
\hline 73 & 6 & 0 & 11.537897 & 2.766943 & 0.000000 \\
\hline 74 & 1 & 0 & 11.526227 & 2.106832 & 0.876939 \\
\hline 75 & 1 & 0 & 11.526227 & 2.106832 & -0.876939 \\
\hline 76 & 6 & 0 & -3.372706 & -11.375583 & 0.000000 \\
\hline 77 & 1 & 0 & -3.938544 & -11.035421 & -0.876939 \\
\hline 78 & 1 & 0 & -3.938544 & -11.035421 & 0.876939 \\
\hline 79 & 6 & 0 & -8.165191 & 8.608640 & 0.000000 \\
\hline 80 & 1 & 0 & -7.587683 & 8.928589 & 0.876939 \\
\hline 81 & 1 & 0 & -7.587683 & 8.928589 & -0.876939 \\
\hline 82 & 6 & 0 & 12.834945 & 3.583968 & 0.000000 \\
\hline 83 & 1 & 0 & 12.845866 & 4.244317 & -0.876712 \\
\hline 84 & 1 & 0 & 12.845866 & 4.244317 & 0.876712 \\
\hline 85 & 6 & 0 & -3.313665 & -12.907372 & 0.000000 \\
\hline 86 & 1 & 0 & -2.747247 & -13.247005 & -0.876712 \\
\hline 87 & 1 & 0 & -2.747247 & -13.247005 & 0.876712 \\
\hline 88 & 6 & 0 & -9.521280 & 9.323404 & 0.000000 \\
\hline 89 & 1 & 0 & -10.098619 & 9.002688 & 0.876712 \\
\hline 90 & 1 & 0 & -10.098619 & 9.002688 & -0.876712 \\
\hline 91 & 6 & 0 & -9.411075 & 10.852415 & 0.000000 \\
\hline 92 & 1 & 0 & -8.833982 & 11.173508 & 0.876811 \\
\hline 93 & 1 & 0 & -8.833982 & 11.173508 & -0.876811 \\
\hline 94 & 6 & 0 & 14.104005 & 2.724023 & 0.000000 \\
\hline 95 & 1 & 0 & 14.093533 & 2.063699 & 0.876811 \\
\hline 96 & 1 & 0 & 14.093533 & 2.063699 & -0.876811 \\
\hline 97 & 6 & 0 & -4.692930 & -13.576438 & 0.000000 \\
\hline 98 & 1 & 0 & -5.259551 & -13.237207 & 0.876811 \\
\hline 99 & 1 & 0 & -5.259551 & -13.237207 & -0.876811 \\
\hline 00 & 6 & 0 & 15.399806 & 3.543035 & 0.000000 \\
\hline
\end{tabular}




\begin{tabular}{|c|c|c|c|c|c|}
\hline 101 & 1 & 0 & 15.409716 & 4.203494 & -0.876703 \\
\hline 102 & 1 & 0 & 15.409716 & 4.203494 & 0.876703 \\
\hline 103 & 6 & 0 & -10.768261 & 11.565106 & 0.000000 \\
\hline 104 & 1 & 0 & -11.345191 & 11.243459 & 0.876703 \\
\hline 105 & 1 & 0 & -11.345191 & 11.243459 & -0.876703 \\
\hline 106 & 6 & 0 & -4.631545 & -15.108141 & 0.000000 \\
\hline 107 & 1 & 0 & -4.064525 & -15.446952 & -0.876703 \\
\hline 108 & 1 & 0 & -4.064525 & -15.446952 & 0.876703 \\
\hline 109 & 6 & 0 & -10.660610 & 13.094311 & 0.000000 \\
\hline 110 & 1 & 0 & -10.083909 & 13.416255 & -0.876771 \\
\hline 111 & 1 & 0 & -10.083909 & 13.416255 & 0.876771 \\
\hline 112 & 6 & 0 & 16.670311 & 2.685204 & 0.000000 \\
\hline 113 & 1 & 0 & 16.660772 & 2.024794 & 0.876771 \\
\hline 114 & 1 & 0 & 16.660772 & 2.024794 & -0.876771 \\
\hline 115 & 6 & 0 & -6.009701 & -15.779515 & 0.000000 \\
\hline 116 & 1 & 0 & -6.576863 & -15.441049 & 0.876771 \\
\hline 117 & 1 & 0 & -6.576863 & -15.441049 & -0.876771 \\
\hline 118 & 6 & 0 & -12.018642 & 13.805425 & 0.000000 \\
\hline 119 & 1 & 0 & -12.595236 & 13.483155 & 0.876706 \\
\hline 120 & 1 & 0 & -12.595236 & 13.483155 & -0.876706 \\
\hline 121 & 6 & 0 & 17.965170 & 3.505737 & 0.000000 \\
\hline 122 & 1 & 0 & 17.974373 & 4.166217 & -0.876706 \\
\hline 123 & 1 & 0 & 17.974373 & 4.166217 & 0.876706 \\
\hline 124 & 6 & 0 & -5.946528 & -17.311162 & 0.000000 \\
\hline 125 & 1 & 0 & -5.379137 & -17.649372 & -0.876706 \\
\hline 126 & 1 & 0 & -5.379137 & -17.649372 & 0.876706 \\
\hline 127 & 6 & 0 & -11.912646 & 15.334723 & 0.000000 \\
\hline 128 & 1 & 0 & -11.336201 & 15.657198 & -0.876773 \\
\hline 129 & 1 & 0 & -11.336201 & 15.657198 & 0.876773 \\
\hline 130 & 6 & 0 & 19.236583 & 2.649293 & 0.000000 \\
\hline 131 & 1 & 0 & 19.227632 & 1.988839 & 0.876773 \\
\hline 132 & 1 & 0 & 19.227632 & 1.988839 & -0.876773 \\
\hline 133 & 6 & 0 & -7.323937 & -17.984016 & 0.000000 \\
\hline 134 & 1 & 0 & -7.891431 & -17.646037 & 0.876773 \\
\hline 135 & 1 & 0 & -7.891431 & -17.646037 & -0.876773 \\
\hline 136 & 6 & 0 & -13.270896 & 16.045004 & 0.000000 \\
\hline 137 & 1 & 0 & -13.848025 & 15.723223 & 0.876744 \\
\hline 138 & 1 & 0 & -13.848025 & 15.723223 & -0.876744 \\
\hline 139 & 6 & 0 & 20.530829 & 3.470431 & 0.000000 \\
\hline
\end{tabular}




\begin{tabular}{|c|c|c|c|c|c|}
\hline 140 & 1 & 0 & 20.540723 & 4.131130 & 0.876744 \\
\hline 141 & 1 & 0 & 20.540723 & 4.131130 & -0.876744 \\
\hline 142 & 6 & 0 & -7.259933 & -19.515435 & 0.000000 \\
\hline 143 & 1 & 0 & -6.692698 & -19.854353 & 0.876744 \\
\hline 144 & 1 & 0 & -6.692698 & -19.854353 & -0.876744 \\
\hline 145 & 6 & 0 & -13.166642 & 17.574450 & 0.000000 \\
\hline 146 & 1 & 0 & -12.590687 & 17.896334 & -0.876158 \\
\hline 147 & 1 & 0 & -12.590687 & 17.896334 & 0.876158 \\
\hline 148 & 6 & 0 & 21.803241 & 2.615421 & 0.000000 \\
\hline 149 & 1 & 0 & 21.794023 & 1.955688 & -0.876158 \\
\hline 150 & 1 & 0 & 21.794023 & 1.955688 & 0.876158 \\
\hline 151 & 6 & 0 & -8.636599 & -20.189871 & 0.000000 \\
\hline 152 & 1 & 0 & -9.203336 & -19.852022 & -0.876158 \\
\hline 153 & 1 & 0 & -9.203336 & -19.852022 & 0.876158 \\
\hline 154 & 6 & 0 & -14.528477 & 18.274806 & 0.000000 \\
\hline 155 & 1 & 0 & -14.419147 & 19.362813 & 0.000000 \\
\hline 156 & 1 & 0 & -15.114404 & 18.000112 & -0.882780 \\
\hline 157 & 1 & 0 & -15.114404 & 18.000112 & 0.882780 \\
\hline 158 & 6 & 0 & 23.090685 & 3.444627 & 0.000000 \\
\hline 159 & 1 & 0 & 23.978261 & 2.805941 & 0.000000 \\
\hline 160 & 1 & 0 & 23.145756 & 4.089402 & -0.882780 \\
\hline 161 & 1 & 0 & 23.145756 & 4.089402 & 0.882780 \\
\hline 162 & 6 & 0 & -8.562208 & -21.719433 & 0.000000 \\
\hline 163 & 1 & 0 & -8.031352 & -22.089514 & 0.882780 \\
\hline 164 & 1 & 0 & -9.559114 & -22.168754 & 0.000000 \\
\hline 165 & 1 & 0 & -8.031352 & -22.089514 & -0.882780 \\
\hline 166 & 6 & 0 & 4.466821 & -5.418839 & 0.000000 \\
\hline 167 & 1 & 0 & 4.736854 & -4.845552 & -0.894036 \\
\hline 168 & 1 & 0 & 4.736854 & -4.845552 & 0.894036 \\
\hline 169 & 1 & 0 & 5.008542 & -6.363119 & 0.000000 \\
\hline 170 & 6 & 0 & 2.459442 & 6.577800 & 0.000000 \\
\hline 171 & 1 & 0 & 1.827944 & 6.525012 & -0.894036 \\
\hline 172 & 1 & 0 & 1.827944 & 6.525012 & 0.894036 \\
\hline 173 & 1 & 0 & 3.006352 & 7.519084 & 0.000000 \\
\hline 174 & 6 & 0 & -6.926263 & -1.158961 & 0.000000 \\
\hline 175 & 1 & 0 & -6.564798 & -1.679460 & -0.894036 \\
\hline 176 & 1 & 0 & -6.564798 & -1.679460 & 0.894036 \\
\hline 177 & 1 & 0 & -8.014894 & -1.155965 & 0.000000 \\
\hline
\end{tabular}




\section{Geometry II- $C_{s}-s y n-1$}

Zero-point correction $=$

1.566993 (Hartree/Particle)

Thermal correction to Energy=

1.654017

Thermal correction to Enthalpy=

1.654961

Thermal correction to Gibbs Free Energy=

1.416945

Sum of electronic and zero-point Energies=

$-3141.240489$

Sum of electronic and thermal Energies=

$-3141.153464$

Sum of electronic and thermal Enthalpies=

$-3141.152520$

Sum of electronic and thermal Free Energies=

$-3141.390536$

Standard orientation:

\begin{tabular}{|c|c|c|c|c|c|}
\hline \multirow{2}{*}{$\begin{array}{l}\text { Center } \\
\text { Number }\end{array}$} & \multirow{2}{*}{$\begin{array}{l}\text { Atomic } \\
\text { Number }\end{array}$} & \multirow{2}{*}{$\begin{array}{l}\text { Atomic } \\
\text { Type }\end{array}$} & \multicolumn{3}{|c|}{ Coordinates (Angstroms) } \\
\hline & & & $\mathrm{X}$ & $\mathrm{Y}$ & Z \\
\hline 1 & 6 & 0 & -2.438609 & 0.452538 & 0.000000 \\
\hline 2 & 6 & 0 & -1.326094 & 1.324382 & 0.000000 \\
\hline 3 & 6 & 0 & -1.548948 & 2.715852 & 0.000000 \\
\hline 4 & 6 & 0 & -2.829231 & 3.249185 & 0.000000 \\
\hline 5 & 6 & 0 & -3.945909 & 2.373167 & 0.000000 \\
\hline 6 & 6 & 0 & -3.735947 & 1.002759 & 0.000000 \\
\hline 7 & 1 & 0 & -0.687346 & 3.367650 & 0.000000 \\
\hline 8 & 1 & 0 & -4.575042 & 0.322027 & 0.000000 \\
\hline 9 & 6 & 0 & -2.265105 & -0.956216 & 0.000000 \\
\hline 10 & 6 & 0 & -2.095615 & -2.155011 & 0.000000 \\
\hline 11 & 6 & 0 & 0.000000 & 0.817876 & 0.000000 \\
\hline 12 & 6 & 0 & 1.122350 & 0.363794 & 0.000000 \\
\hline 13 & 6 & 0 & -1.871604 & -3.556750 & 0.000000 \\
\hline 14 & 6 & 0 & -0.560792 & -4.085525 & 0.000000 \\
\hline 15 & 6 & 0 & -2.966106 & -4.444306 & 0.000000 \\
\hline 16 & 6 & 0 & -0.390328 & -5.484415 & 0.000000 \\
\hline 17 & 6 & 0 & -2.789680 & -5.820044 & 0.000000 \\
\hline 18 & 1 & 0 & -3.960751 & -4.022685 & 0.000000 \\
\hline 19 & 6 & 0 & -1.473128 & -6.350337 & 0.000000 \\
\hline 20 & 1 & 0 & 0.618325 & -5.871891 & 0.000000 \\
\hline 21 & 6 & 0 & 2.429008 & -0.190669 & 0.000000 \\
\hline 22 & 6 & 0 & 3.553992 & 0.658016 & 0.000000 \\
\hline 23 & 6 & 0 & 2.628186 & -1.590065 & 0.000000 \\
\hline
\end{tabular}




\begin{tabular}{|c|c|c|c|c|}
\hline 6 & 0 & 4.845890 & 0.155076 & 0.000000 \\
\hline 1 & 0 & 3.383717 & 1.725016 & 0.000000 \\
\hline 6 & 0 & 3.944880 & -2.092348 & 0.000000 \\
\hline 6 & 0 & 5.046662 & -1.249924 & 0.000000 \\
\hline 1 & 0 & 4.078811 & -3.164393 & 0.000000 \\
\hline 6 & 0 & 0.573357 & -3.231926 & 0.000000 \\
\hline 6 & 0 & 1.527079 & -2.486038 & 0.000000 \\
\hline 8 & 0 & 6.340940 & -1.657150 & 0.000000 \\
\hline 8 & 0 & 5.976000 & 0.908674 & 0.000000 \\
\hline 8 & 0 & -3.122953 & 4.573864 & 0.000000 \\
\hline 8 & 0 & -5.163393 & 2.975444 & 0.000000 \\
\hline 8 & 0 & -3.791118 & -6.735428 & 0.000000 \\
\hline 8 & 0 & -1.387332 & -7.705947 & 0.000000 \\
\hline 6 & 0 & -2.051820 & 5.518953 & 0.000000 \\
\hline 1 & 0 & -1.424420 & 5.370329 & 0.888557 \\
\hline 1 & 0 & -1.424420 & 5.370329 & -0.888557 \\
\hline 6 & 0 & -5.144968 & -6.275500 & 0.000000 \\
\hline 1 & 0 & -5.321624 & -5.657371 & 0.887771 \\
\hline 1 & 0 & -5.321624 & -5.657371 & -0.887771 \\
\hline 6 & 0 & 6.625316 & -3.057029 & 0.000000 \\
\hline 1 & 0 & 6.183531 & -3.526615 & 0.888576 \\
\hline 1 & 0 & 6.183531 & -3.526615 & -0.888576 \\
\hline 6 & 0 & -2.667792 & 6.908857 & 0.000000 \\
\hline 1 & 0 & -3.314832 & 7.001690 & -0.878387 \\
\hline 1 & 0 & -3.314832 & 7.001690 & 0.878387 \\
\hline 6 & 0 & 8.137216 & -3.216239 & 0.000000 \\
\hline 1 & 0 & 8.540265 & -2.701548 & 0.878353 \\
\hline 1 & 0 & 8.540265 & -2.701548 & -0.878353 \\
\hline 6 & 0 & -6.022784 & -7.521734 & 0.000000 \\
\hline 1 & 0 & -5.736722 & -8.114978 & 0.872355 \\
\hline 1 & 0 & -5.736722 & -8.114978 & -0.872355 \\
\hline 6 & 0 & -1.613900 & 8.021613 & 0.000000 \\
\hline 1 & 0 & -0.963843 & 7.911386 & -0.877454 \\
\hline 1 & 0 & -0.963843 & 7.911386 & 0.877454 \\
\hline 6 & 0 & 8.576879 & -4.684423 & 0.000000 \\
\hline 1 & 0 & 8.157512 & -5.193193 & -0.877459 \\
\hline 1 & 0 & 8.157512 & -5.193193 & 0.877459 \\
\hline 6 & 0 & -7.561669 & -7.282231 & 0.000000 \\
\hline 1 & 0 & -7.994806 & -7.783992 & -0.871345 \\
\hline
\end{tabular}




\begin{tabular}{|c|c|c|c|c|c|}
\hline 63 & 1 & 0 & -7.994806 & -7.783992 & 0.871345 \\
\hline 64 & 6 & 0 & -2.224231 & 9.428001 & 0.000000 \\
\hline 65 & 1 & 0 & -2.874806 & 9.538455 & 0.876738 \\
\hline 66 & 1 & 0 & -2.874806 & 9.538455 & -0.876738 \\
\hline 67 & 6 & 0 & 10.100412 & -4.855359 & 0.000000 \\
\hline 68 & 1 & 0 & 10.520041 & -4.346018 & 0.876708 \\
\hline 69 & 1 & 0 & 10.520041 & -4.346018 & -0.876708 \\
\hline 70 & 6 & 0 & -8.055307 & -5.825741 & 0.000000 \\
\hline 71 & 1 & 0 & -7.667959 & -5.295331 & -0.877944 \\
\hline 72 & 1 & 0 & -7.667959 & -5.295331 & 0.877944 \\
\hline 73 & 6 & 0 & -1.179498 & 10.549503 & 0.000000 \\
\hline 74 & 1 & 0 & -0.528756 & 10.438007 & 0.876935 \\
\hline 75 & 1 & 0 & -0.528756 & 10.438007 & -0.876935 \\
\hline 76 & 6 & 0 & 10.553434 & -6.319604 & 0.000000 \\
\hline 77 & 1 & 0 & 10.133026 & -6.828671 & -0.876940 \\
\hline 78 & 1 & 0 & 10.133026 & -6.828671 & 0.876940 \\
\hline 79 & 6 & 0 & -9.585414 & -5.726577 & 0.000000 \\
\hline 80 & 1 & 0 & -9.981335 & -6.254920 & -0.876809 \\
\hline 81 & 1 & 0 & -9.981335 & -6.254920 & 0.876809 \\
\hline 82 & 6 & 0 & -1.790560 & 11.955380 & 0.000000 \\
\hline 83 & 1 & 0 & -2.441609 & 12.066296 & -0.876718 \\
\hline 84 & 1 & 0 & -2.441609 & 12.066296 & 0.876718 \\
\hline 85 & 6 & 0 & 12.077008 & -6.488569 & 0.000000 \\
\hline 86 & 1 & 0 & 12.496939 & -5.978787 & -0.876697 \\
\hline 87 & 1 & 0 & 12.496939 & -5.978787 & 0.876697 \\
\hline 88 & 6 & 0 & -10.106590 & -4.284982 & 0.000000 \\
\hline 89 & 1 & 0 & -9.710082 & -3.757088 & -0.876971 \\
\hline 90 & 1 & 0 & -9.710082 & -3.757088 & 0.876971 \\
\hline 91 & 6 & 0 & -11.636272 & -4.184861 & 0.000000 \\
\hline 92 & 1 & 0 & -12.033065 & -4.712684 & -0.876782 \\
\hline 93 & 1 & 0 & -12.033065 & -4.712684 & 0.876782 \\
\hline 94 & 6 & 0 & -0.748000 & 13.079204 & 0.000000 \\
\hline 95 & 1 & 0 & -0.096923 & 12.968522 & 0.876807 \\
\hline 96 & 1 & 0 & -0.096923 & 12.968522 & -0.876807 \\
\hline 97 & 6 & 0 & 12.534001 & -7.951809 & 0.000000 \\
\hline 98 & 1 & 0 & 12.114401 & -8.461799 & 0.876809 \\
\hline 99 & 1 & 0 & 12.114401 & -8.461799 & -0.876809 \\
\hline 100 & 6 & 0 & -1.360468 & 14.484478 & 0.000000 \\
\hline 101 & 1 & 0 & -2.011717 & 14.594769 & -0.876713 \\
\hline
\end{tabular}




\begin{tabular}{|c|c|c|c|c|c|}
\hline 102 & 1 & 0 & -2.011717 & 14.594769 & 0.876713 \\
\hline 103 & 6 & 0 & -12.157214 & -2.743122 & 0.000000 \\
\hline 104 & 1 & 0 & -11.760166 & -2.215413 & -0.876877 \\
\hline 105 & 1 & 0 & -11.760166 & -2.215413 & 0.876877 \\
\hline 106 & 6 & 0 & 14.057833 & -8.118515 & 0.000000 \\
\hline 107 & 1 & 0 & 14.477096 & -7.608080 & -0.876700 \\
\hline 108 & 1 & 0 & 14.477096 & -7.608080 & 0.876700 \\
\hline 109 & 6 & 0 & -13.686789 & -2.641795 & 0.000000 \\
\hline 110 & 1 & 0 & -14.083963 & -3.169457 & 0.876755 \\
\hline 111 & 1 & 0 & -14.083963 & -3.169457 & -0.876755 \\
\hline 112 & 6 & 0 & -0.319283 & 15.609595 & 0.000000 \\
\hline 113 & 1 & 0 & 0.331973 & 15.499576 & 0.876769 \\
\hline 114 & 1 & 0 & 0.331973 & 15.499576 & -0.876769 \\
\hline 115 & 6 & 0 & 14.517175 & -9.581033 & 0.000000 \\
\hline 116 & 1 & 0 & 14.098220 & -10.091644 & 0.876768 \\
\hline 117 & 1 & 0 & 14.098220 & -10.091644 & -0.876768 \\
\hline 118 & 6 & 0 & -14.207119 & -1.199831 & 0.000000 \\
\hline 119 & 1 & 0 & -13.809835 & -0.672204 & -0.876792 \\
\hline 120 & 1 & 0 & -13.809835 & -0.672204 & 0.876792 \\
\hline 121 & 6 & 0 & -0.932977 & 17.014341 & 0.000000 \\
\hline 122 & 1 & 0 & -1.584327 & 17.124121 & -0.876712 \\
\hline 123 & 1 & 0 & -1.584327 & 17.124121 & 0.876712 \\
\hline 124 & 6 & 0 & 16.041206 & -9.746005 & 0.000000 \\
\hline 125 & 1 & 0 & 16.459959 & -9.235144 & -0.876704 \\
\hline 126 & 1 & 0 & 16.459959 & -9.235144 & 0.876704 \\
\hline 127 & 6 & 0 & -15.736674 & -1.097879 & 0.000000 \\
\hline 128 & 1 & 0 & -16.134062 & -1.625446 & 0.876767 \\
\hline 129 & 1 & 0 & -16.134062 & -1.625446 & -0.876767 \\
\hline 130 & 6 & 0 & 0.107286 & 18.140336 & 0.000000 \\
\hline 131 & 1 & 0 & 0.758647 & 18.030757 & 0.876773 \\
\hline 132 & 1 & 0 & 0.758647 & 18.030757 & -0.876773 \\
\hline 133 & 6 & 0 & 16.502030 & -11.208076 & 0.000000 \\
\hline 134 & 1 & 0 & 16.083471 & -11.719057 & 0.876770 \\
\hline 135 & 1 & 0 & 16.083471 & -11.719057 & -0.876770 \\
\hline 136 & 6 & 0 & -16.256862 & 0.343936 & 0.000000 \\
\hline 137 & 1 & 0 & -15.860149 & 0.872328 & -0.876778 \\
\hline 138 & 1 & 0 & -15.860149 & 0.872328 & 0.876778 \\
\hline 139 & 6 & 0 & -0.506856 & 19.544685 & 0.000000 \\
\hline 140 & 1 & 0 & -1.158305 & 19.655264 & 0.876748 \\
\hline
\end{tabular}




\begin{tabular}{|c|c|c|c|c|c|}
\hline 141 & 1 & 0 & -1.158305 & 19.655264 & -0.876748 \\
\hline 142 & 6 & 0 & 18.025955 & -11.372319 & 0.000000 \\
\hline 143 & 1 & 0 & 18.445435 & -10.861761 & 0.876741 \\
\hline 144 & 1 & 0 & 18.445435 & -10.861761 & -0.876741 \\
\hline 145 & 6 & 0 & -17.786370 & 0.447095 & 0.000000 \\
\hline 146 & 1 & 0 & -18.183011 & -0.080146 & 0.876157 \\
\hline 147 & 1 & 0 & -18.183011 & -0.080146 & -0.876157 \\
\hline 148 & 6 & 0 & 0.532262 & 20.671778 & 0.000000 \\
\hline 149 & 1 & 0 & 1.182864 & 20.562010 & -0.876158 \\
\hline 150 & 1 & 0 & 1.182864 & 20.562010 & 0.876158 \\
\hline 151 & 6 & 0 & 18.488343 & -12.833918 & 0.000000 \\
\hline 152 & 1 & 0 & 18.070013 & -13.344155 & -0.876158 \\
\hline 153 & 1 & 0 & 18.070013 & -13.344155 & 0.876158 \\
\hline 154 & 6 & 0 & -18.296500 & 1.891005 & 0.000000 \\
\hline 155 & 1 & 0 & -19.389295 & 1.929451 & 0.000000 \\
\hline 156 & 1 & 0 & -17.945303 & 2.434507 & 0.882793 \\
\hline 157 & 1 & 0 & -17.945303 & 2.434507 & -0.882793 \\
\hline 158 & 6 & 0 & -0.090824 & 22.070661 & 0.000000 \\
\hline 159 & 1 & 0 & 0.675799 & 22.850405 & 0.000000 \\
\hline 160 & 1 & 0 & -0.719640 & 22.223461 & -0.882780 \\
\hline 161 & 1 & 0 & -0.719640 & 22.223461 & 0.882780 \\
\hline 162 & 6 & 0 & 20.011977 & -12.987671 & 0.000000 \\
\hline 163 & 1 & 0 & 20.456865 & -12.517729 & 0.882779 \\
\hline 164 & 1 & 0 & 20.308142 & -14.040287 & 0.000000 \\
\hline 165 & 1 & 0 & 20.456865 & -12.517729 & -0.882779 \\
\hline 166 & 6 & 0 & 5.840758 & 2.322199 & 0.000000 \\
\hline 167 & 1 & 0 & 5.314775 & 2.675691 & 0.894020 \\
\hline 168 & 1 & 0 & 6.855971 & 2.715237 & 0.000000 \\
\hline 169 & 1 & 0 & 5.314775 & 2.675691 & -0.894020 \\
\hline 170 & 6 & 0 & -6.320180 & 2.151883 & 0.000000 \\
\hline 171 & 1 & 0 & -6.363514 & 1.519631 & -0.894004 \\
\hline 172 & 1 & 0 & -6.363514 & 1.519631 & 0.894004 \\
\hline 173 & 1 & 0 & -7.167956 & 2.834815 & 0.000000 \\
\hline 174 & 6 & 0 & -0.096361 & -8.297249 & 0.000000 \\
\hline 175 & 1 & 0 & 0.473116 & -8.019214 & -0.894025 \\
\hline 176 & 1 & 0 & 0.473116 & -8.019214 & 0.894025 \\
\hline 177 & 1 & 0 & -0.264984 & -9.372750 & 0.000000 \\
\hline
\end{tabular}




\section{Geometry III- $C_{s}-$ syn-2}

Zero-point correction=

1.566534 (Hartree/Particle)

Thermal correction to Energy=

1.652898

Thermal correction to Enthalpy=

1.653843

Thermal correction to Gibbs Free Energy=

1.417137

Sum of electronic and zero-point Energies=

$-3141.236260$

Sum of electronic and thermal Energies=

$-3141.149896$

Sum of electronic and thermal Enthalpies=

$-3141.148952$

Sum of electronic and thermal Free Energies=

$-3141.385657$

Standard orientation:

\begin{tabular}{|c|c|c|c|c|c|}
\hline \multirow{2}{*}{$\begin{array}{l}\text { Center } \\
\text { Number }\end{array}$} & \multirow{2}{*}{$\begin{array}{l}\text { Atomic } \\
\text { Number }\end{array}$} & \multirow{2}{*}{$\begin{array}{l}\text { Atomic } \\
\text { Type }\end{array}$} & \multicolumn{3}{|c|}{ Coordinates (Angstroms) } \\
\hline & & & $\mathrm{X}$ & $\mathrm{Y}$ & Z \\
\hline 1 & 6 & 0 & 2.437816 & -0.385808 & 0.000000 \\
\hline 2 & 6 & 0 & 1.328624 & -1.262244 & 0.000000 \\
\hline 3 & 6 & 0 & 1.557420 & -2.653167 & 0.000000 \\
\hline 4 & 6 & 0 & 2.839655 & -3.181428 & 0.000000 \\
\hline 5 & 6 & 0 & 3.952652 & -2.300874 & 0.000000 \\
\hline 6 & 6 & 0 & 3.737238 & -0.931508 & 0.000000 \\
\hline 7 & 1 & 0 & 0.698175 & -3.308140 & 0.000000 \\
\hline 8 & 1 & 0 & 4.573941 & -0.247803 & 0.000000 \\
\hline 9 & 6 & 0 & 2.259849 & 1.022193 & 0.000000 \\
\hline 10 & 6 & 0 & 2.086873 & 2.220699 & 0.000000 \\
\hline 11 & 6 & 0 & 0.000000 & -0.763079 & 0.000000 \\
\hline 12 & 6 & 0 & -1.125494 & -0.316184 & 0.000000 \\
\hline 13 & 6 & 0 & 1.851340 & 3.620114 & 0.000000 \\
\hline 14 & 6 & 0 & 0.533346 & 4.143653 & 0.000000 \\
\hline 15 & 6 & 0 & 2.928930 & 4.518054 & 0.000000 \\
\hline 16 & 6 & 0 & 0.368324 & 5.532447 & 0.000000 \\
\hline 17 & 6 & 0 & 2.754769 & 5.900825 & 0.000000 \\
\hline 18 & 1 & 0 & 3.926339 & 4.103850 & 0.000000 \\
\hline 19 & 6 & 0 & 1.438856 & 6.424447 & 0.000000 \\
\hline 20 & 1 & 0 & -0.626986 & 5.957474 & 0.000000 \\
\hline 21 & 6 & 0 & -2.435087 & 0.230740 & 0.000000 \\
\hline 22 & 6 & 0 & -3.556624 & -0.622795 & 0.000000 \\
\hline 23 & 6 & 0 & -2.640600 & 1.629172 & 0.000000 \\
\hline
\end{tabular}




\begin{tabular}{|c|c|c|c|c|}
\hline 6 & 0 & -4.850456 & -0.124840 & 0.000000 \\
\hline 1 & 0 & -3.382181 & -1.689135 & 0.000000 \\
\hline 6 & 0 & -3.959023 & 2.126341 & 0.000000 \\
\hline 6 & 0 & -5.057305 & 1.279517 & 0.000000 \\
\hline 1 & 0 & -4.096664 & 3.197816 & 0.000000 \\
\hline 6 & 0 & -0.596160 & 3.283047 & 0.000000 \\
\hline 6 & 0 & -1.543788 & 2.530299 & 0.000000 \\
\hline 8 & 0 & -6.353027 & 1.681750 & 0.000000 \\
\hline 8 & 0 & -5.977680 & -0.882672 & 0.000000 \\
\hline 8 & 0 & 3.138404 & -4.505070 & 0.000000 \\
\hline 8 & 0 & 5.172959 & -2.898196 & 0.000000 \\
\hline 8 & 0 & 3.799026 & 6.786160 & 0.000000 \\
\hline 8 & 0 & 1.063866 & 7.734055 & 0.000000 \\
\hline 6 & 0 & 2.070097 & -5.453020 & 0.000000 \\
\hline 1 & 0 & 1.442176 & -5.305879 & 0.888427 \\
\hline 1 & 0 & 1.442176 & -5.305879 & -0.888427 \\
\hline 6 & 0 & 5.137698 & 6.282076 & 0.000000 \\
\hline 1 & 0 & 5.293824 & 5.659249 & 0.887854 \\
\hline 1 & 0 & 5.293824 & 5.659249 & -0.887854 \\
\hline 6 & 0 & -6.641164 & 3.081476 & 0.000000 \\
\hline 1 & 0 & -6.200018 & 3.551675 & 0.888456 \\
\hline 1 & 0 & -6.200018 & 3.551675 & -0.888456 \\
\hline 6 & 0 & 2.689057 & -6.841643 & 0.000000 \\
\hline 1 & 0 & 3.336068 & -6.933453 & -0.878531 \\
\hline 1 & 0 & 3.336068 & -6.933453 & 0.878531 \\
\hline 6 & 0 & -8.153192 & 3.237815 & 0.000000 \\
\hline 1 & 0 & -8.555454 & 2.722479 & 0.878410 \\
\hline 1 & 0 & -8.555454 & 2.722479 & -0.878410 \\
\hline 6 & 0 & 6.062593 & 7.494377 & 0.000000 \\
\hline 1 & 0 & 5.804613 & 8.099165 & 0.873537 \\
\hline 1 & 0 & 5.804613 & 8.099165 & -0.873537 \\
\hline 6 & 0 & 1.636113 & -7.955202 & 0.000000 \\
\hline 1 & 0 & 0.985761 & -7.845389 & -0.877287 \\
\hline 1 & 0 & 0.985761 & -7.845389 & 0.877287 \\
\hline 6 & 0 & -8.594797 & 4.705208 & 0.000000 \\
\hline 1 & 0 & -8.175812 & 5.214438 & -0.877323 \\
\hline 1 & 0 & -8.175812 & 5.214438 & 0.877323 \\
\hline 6 & 0 & 7.591295 & 7.193942 & 0.000000 \\
\hline 1 & 0 & 8.043493 & 7.678084 & -0.871509 \\
\hline
\end{tabular}




\begin{tabular}{|c|c|c|c|c|c|}
\hline 63 & 1 & 0 & 8.043493 & 7.678084 & 0.871509 \\
\hline 64 & 6 & 0 & 2.246209 & -9.361749 & 0.000000 \\
\hline 65 & 1 & 0 & 2.896504 & -9.472491 & 0.876932 \\
\hline 66 & 1 & 0 & 2.896504 & -9.472491 & -0.876932 \\
\hline 67 & 6 & 0 & -10.118463 & 4.874452 & 0.000000 \\
\hline 68 & 1 & 0 & -10.537797 & 4.364883 & 0.876802 \\
\hline 69 & 1 & 0 & -10.537797 & 4.364883 & -0.876802 \\
\hline 70 & 6 & 0 & 8.026984 & 5.719485 & 0.000000 \\
\hline 71 & 1 & 0 & 7.619899 & 5.204267 & -0.878009 \\
\hline 72 & 1 & 0 & 7.619899 & 5.204267 & 0.878009 \\
\hline 73 & 6 & 0 & 1.200135 & -10.481735 & 0.000000 \\
\hline 74 & 1 & 0 & 0.549416 & -10.369280 & 0.876834 \\
\hline 75 & 1 & 0 & 0.549416 & -10.369280 & -0.876834 \\
\hline 76 & 6 & 0 & -10.572149 & 6.338317 & 0.000000 \\
\hline 77 & 1 & 0 & -10.151645 & 6.847559 & -0.876776 \\
\hline 78 & 1 & 0 & -10.151645 & 6.847559 & 0.876776 \\
\hline 79 & 6 & 0 & 9.552294 & 5.563115 & 0.000000 \\
\hline 80 & 1 & 0 & 9.967759 & 6.076005 & -0.876948 \\
\hline 81 & 1 & 0 & 9.967759 & 6.076005 & 0.876948 \\
\hline 82 & 6 & 0 & 1.808447 & -11.888899 & 0.000000 \\
\hline 83 & 1 & 0 & 2.459082 & -12.001170 & -0.876876 \\
\hline 84 & 1 & 0 & 2.459082 & -12.001170 & 0.876876 \\
\hline 85 & 6 & 0 & -12.095704 & 6.507155 & 0.000000 \\
\hline 86 & 1 & 0 & -12.515729 & 5.997474 & -0.876783 \\
\hline 87 & 1 & 0 & -12.515729 & 5.997474 & 0.876783 \\
\hline 88 & 6 & 0 & 10.019646 & 4.103341 & 0.000000 \\
\hline 89 & 1 & 0 & 9.604037 & 3.590292 & -0.876932 \\
\hline 90 & 1 & 0 & 9.604037 & 3.590292 & 0.876932 \\
\hline 91 & 6 & 0 & 11.544738 & 3.948446 & 0.000000 \\
\hline 92 & 1 & 0 & 11.960048 & 4.461868 & -0.876786 \\
\hline 93 & 1 & 0 & 11.960048 & 4.461868 & 0.876786 \\
\hline 94 & 6 & 0 & 0.762826 & -13.009620 & 0.000000 \\
\hline 95 & 1 & 0 & 0.111935 & -12.896956 & 0.876694 \\
\hline 96 & 1 & 0 & 0.111935 & -12.896956 & -0.876694 \\
\hline 97 & 6 & 0 & -12.552186 & 7.970394 & 0.000000 \\
\hline 98 & 1 & 0 & -12.132081 & 8.480271 & 0.876638 \\
\hline 99 & 1 & 0 & -12.132081 & 8.480271 & -0.876638 \\
\hline 100 & 6 & 0 & 1.370533 & -14.417082 & 0.000000 \\
\hline 101 & 1 & 0 & 2.021210 & -14.529638 & -0.876859 \\
\hline
\end{tabular}




\begin{tabular}{|c|c|c|c|c|c|}
\hline 102 & 1 & 0 & 2.021210 & -14.529638 & 0.876859 \\
\hline 103 & 6 & 0 & 12.014673 & 2.489459 & 0.000000 \\
\hline 104 & 1 & 0 & 11.599491 & 1.975815 & -0.876847 \\
\hline 105 & 1 & 0 & 11.599491 & 1.975815 & 0.876847 \\
\hline 106 & 6 & 0 & -14.075863 & 8.138371 & 0.000000 \\
\hline 107 & 1 & 0 & -14.495611 & 7.628391 & -0.876787 \\
\hline 108 & 1 & 0 & -14.495611 & 7.628391 & 0.876787 \\
\hline 109 & 6 & 0 & 13.539887 & 2.335835 & 0.000000 \\
\hline 110 & 1 & 0 & 13.954746 & 2.849778 & 0.876744 \\
\hline 111 & 1 & 0 & 13.954746 & 2.849778 & -0.876744 \\
\hline 112 & 6 & 0 & 0.324843 & -15.537802 & 0.000000 \\
\hline 113 & 1 & 0 & -0.326057 & -15.424966 & 0.876672 \\
\hline 114 & 1 & 0 & -0.326057 & -15.424966 & -0.876672 \\
\hline 115 & 6 & 0 & -14.533396 & 9.601298 & 0.000000 \\
\hline 116 & 1 & 0 & -14.113509 & 10.111445 & 0.876608 \\
\hline 117 & 1 & 0 & -14.113509 & 10.111445 & -0.876608 \\
\hline 118 & 6 & 0 & 14.011436 & 0.877346 & 0.000000 \\
\hline 119 & 1 & 0 & 13.596733 & 0.363197 & -0.876755 \\
\hline 120 & 1 & 0 & 13.596733 & 0.363197 & 0.876755 \\
\hline 121 & 6 & 0 & 0.932084 & -16.945484 & 0.000000 \\
\hline 122 & 1 & 0 & 1.582757 & -17.058301 & -0.876828 \\
\hline 123 & 1 & 0 & 1.582757 & -17.058301 & 0.876828 \\
\hline 124 & 6 & 0 & -16.057140 & 9.768937 & 0.000000 \\
\hline 125 & 1 & 0 & -16.476837 & 9.258894 & -0.876771 \\
\hline 126 & 1 & 0 & -16.476837 & 9.258894 & 0.876771 \\
\hline 127 & 6 & 0 & 15.536801 & 0.724870 & 0.000000 \\
\hline 128 & 1 & 0 & 15.951338 & 1.239177 & 0.876737 \\
\hline 129 & 1 & 0 & 15.951338 & 1.239177 & -0.876737 \\
\hline 130 & 6 & 0 & -0.113831 & -18.066051 & 0.000000 \\
\hline 131 & 1 & 0 & -0.764658 & -17.953071 & 0.876728 \\
\hline 132 & 1 & 0 & -0.764658 & -17.953071 & -0.876728 \\
\hline 133 & 6 & 0 & -16.514913 & 11.231801 & 0.000000 \\
\hline 134 & 1 & 0 & -16.095068 & 11.741966 & 0.876655 \\
\hline 135 & 1 & 0 & -16.095068 & 11.741966 & -0.876655 \\
\hline 136 & 6 & 0 & 16.009613 & -0.733039 & 0.000000 \\
\hline 137 & 1 & 0 & 15.596059 & -1.248374 & -0.876791 \\
\hline 138 & 1 & 0 & 15.596059 & -1.248374 & 0.876791 \\
\hline 139 & 6 & 0 & 0.492722 & -19.473837 & 0.000000 \\
\hline 140 & 1 & 0 & 1.143509 & -19.587909 & 0.876776 \\
\hline
\end{tabular}




\begin{tabular}{|c|c|c|c|c|c|}
\hline 141 & 1 & 0 & 1.143509 & -19.587909 & -0.876776 \\
\hline 142 & 6 & 0 & -18.038470 & 11.399802 & 0.000000 \\
\hline 143 & 1 & 0 & -18.459283 & 10.890331 & 0.876772 \\
\hline 144 & 1 & 0 & -18.459283 & 10.890331 & -0.876772 \\
\hline 145 & 6 & 0 & 17.534988 & -0.885654 & 0.000000 \\
\hline 146 & 1 & 0 & 17.948512 & -0.371416 & 0.876091 \\
\hline 147 & 1 & 0 & 17.948512 & -0.371416 & -0.876091 \\
\hline 148 & 6 & 0 & -0.552671 & -20.594931 & 0.000000 \\
\hline 149 & 1 & 0 & -1.202588 & -20.481483 & -0.876209 \\
\hline 150 & 1 & 0 & -1.202588 & -20.481483 & 0.876209 \\
\hline 151 & 6 & 0 & -18.496900 & 12.862488 & 0.000000 \\
\hline 152 & 1 & 0 & -18.077100 & 13.371578 & -0.876140 \\
\hline 153 & 1 & 0 & -18.077100 & 13.371578 & 0.876140 \\
\hline 154 & 6 & 0 & 17.998518 & -2.345151 & 0.000000 \\
\hline 155 & 1 & 0 & 19.089507 & -2.418632 & 0.000000 \\
\hline 156 & 1 & 0 & 17.630117 & -2.877145 & 0.882794 \\
\hline 157 & 1 & 0 & 17.630117 & -2.877145 & -0.882794 \\
\hline 158 & 6 & 0 & 0.062322 & -21.997455 & 0.000000 \\
\hline 159 & 1 & 0 & -0.708827 & -22.772730 & 0.000000 \\
\hline 160 & 1 & 0 & 0.690263 & -22.153922 & -0.882775 \\
\hline 161 & 1 & 0 & 0.690263 & -22.153922 & 0.882775 \\
\hline 162 & 6 & 0 & -20.020026 & 13.020947 & 0.000000 \\
\hline 163 & 1 & 0 & -20.466605 & 12.552484 & 0.882730 \\
\hline 164 & 1 & 0 & -20.312841 & 14.074501 & 0.000000 \\
\hline 165 & 1 & 0 & -20.466605 & 12.552484 & -0.882730 \\
\hline 166 & 6 & 0 & -5.837188 & -2.295583 & 0.000000 \\
\hline 167 & 1 & 0 & -5.310050 & -2.647195 & 0.894075 \\
\hline 168 & 1 & 0 & -6.851013 & -2.692246 & 0.000000 \\
\hline 169 & 1 & 0 & -5.310050 & -2.647195 & -0.894075 \\
\hline 170 & 6 & 0 & 6.326199 & -2.070173 & 0.000000 \\
\hline 171 & 1 & 0 & 6.367097 & -1.437582 & -0.893967 \\
\hline 172 & 1 & 0 & 6.367097 & -1.437582 & 0.893967 \\
\hline 173 & 1 & 0 & 7.177049 & -2.749333 & 0.000000 \\
\hline 174 & 6 & 0 & 1.984337 & 8.827266 & 0.000000 \\
\hline 175 & 1 & 0 & 2.614958 & 8.824499 & 0.890033 \\
\hline 176 & 1 & 0 & 2.614958 & 8.824499 & -0.890033 \\
\hline 177 & 1 & 0 & 1.352983 & 9.715669 & 0.000000 \\
\hline
\end{tabular}




\section{References.}

(1) Tahara, K.; Adisoejoso, J.; Inukai, K.; Lei, S.; Noguchi, A.; Li, B.; Vanderlinden, W.; De Feyter, S.; Tobe, Y. Harnessing by a Diacetylene Unit: a Molecular Design for Porous Two-Dimensional Network Formation at the Liquid/Solid Interface. Chem. Commun. 2014, 50, 2831-2833.

(2) Tahara, K.; Yamaga, H.; Ghijsens, E.; Inukai, K.; Adisoejoso, J.; Blunt, M. O.; De Feyter, S.; Tobe, Y. Control and Induction of Surface-Confined Homochiral Porous Molecular Networks. Nat. Chem. 2011, 3, 714-719.

(3) Tahara, K.; Inukai, K.; Adisoejoso, J.; Yamaga, H.; Balandina, T.; Blunt, M. O.; De Feyter, S.; Tobe, Y. Tailoring Surface-Confined Nanopores with Photoresponsive Groups. Angew. Chem. Int. Ed. 2013, 52, 8373-8376.

(4) Tahara, K.; Okuhata, S.; Adisoejoso, J.; Lei, S.; Fujita, T.; De Feyter, S.; Tobe, Y. 2D Networks of Rhombic-Shaped Fused Dehydrobenzo[12]annulenes: Structural Variations under Concentration Control. J. Am. Chem. Soc. 2009, 131, 17583-17590.

(5) Duniz, J. D.; Gavezzotti, A. Supramolecular Synthons: Validation and Ranking of Intermolecular Interaction Energies. Cryst. Growth Des. 2012, 12, 5873-5877.

(6) Blunt, M. O.; Adisoejoso, J.; Tahara, K.; Katayama, K.; Van der Auweraer, M.; Tobe, Y.; De Feyter, S. Temperature-Induced Structural Phase Transitions in a Two-Dimensional Self-Assembled Network. J. Am. Chem. Soc. 2013, 135, 12068-12075.

(7) Gutzler, R.; Sirtl, T.; Dienstmaier, J. F.; Mahata, K.; Heckl, W. M.; Schmittel, M.; Lackinger, M. Reversible Phase Transitions in Self-Assembled Monolayers at the Liquid-Solid Interface: Temperature-Controlled Opening and Closing of Nanopores. J. Am. Chem. Soc. 2010, 132, 50845090.

(8) Frisch, M. J.; Trucks, G. W.; Schlegel, H. B.; Scuseria, G. E.; Robb, M. A.; Cheeseman, J. R.; Scalmani, G.; Barone, V.; Petersson, G. A.; Nakatsuji, H.; Li, X.; Caricato, M.; Marenich, A. V.; Bloino, J.; Janesko, B. G.; Gomperts, R.; Mennucci, B.; Hratchian, H. P.; Ortiz, J. V.; Izmaylov, A. F.; Sonnenberg, J. L.; Williams-Young, D.; Ding, F.; Lipparini, F.; Egidi, F.; Goings, J.; Peng, B.; 
Petrone, A.; Henderson, T.; Ranasinghe, D.; Zakrzewski, V. G.; Gao, J.; Rega, N.; Zheng, G.; Liang, W.; Hada, M.; Ehara, M.; Toyota, K.; Fukuda, R.; Hasegawa, J.; Ishida, M.; Nakajima, T.; Honda, Y.; Kitao, O.; Nakai, H.; Vreven, T.; Throssell, K.; Montgomery, J. A., Jr.; Peralta, J. E.; Ogliaro, F.; Bearpark, M. J.; Heyd, J. J.; Brothers, E. N.; Kudin, K. N.; Staroverov, V. N.; Keith, T. A.; Kobayashi, R.; Normand, J.; Raghavachari, K.; Rendell, A. P.; Burant, J. C.; Iyengar, S. S.; Tomasi, J.; Cossi, M.; Millam, J. M.; Klene, M.; Adamo, C.; Cammi, R.; Ochterski, J. W.; Martin, R. L.; Morokuma, K.; Farkas, O.; Foresman, J. B.; Fox, D. J. Gaussian 16, Revision A.03, Gaussian, Inc., Wallingford CT, 2016.

(9) Mammen, M.; Shakhnovich, E. I.; Deutch, J. M.; Whitesides, G. M. Estimating the Entropic Cost of Self-Assembly of Multiparticle Hydrogen-Bonded Aggregates Based on the Cyanuric Acid·Melamine Lattice. J. Org. Chem. 1998, 63, 3821-3830.

(10) Mammen, M.; Shakhnovich, E. I.; Whitesides, G. M. Using a Convenient, Quantitative Model for Torsional Entropy to Establish Qualitative Trends for Molecular Processes That Restrict Conformational Freedom. J. Org. Chem. 1998, 63, 3168-3175. 